NBER WORKING PAPER SERIES

\title{
DOES SHORT-TERM DEBT INCREASE VULNERABILITY TO CRISIS? EVIDENCE FROM THE EAST ASIAN FINANCIAL CRISIS
}

\author{
Efraim Benmelech \\ Eyal Dvir \\ Working Paper 17468 \\ http://www.nber.org/papers/w17468 \\ NATIONAL BUREAU OF ECONOMIC RESEARCH \\ 1050 Massachusetts Avenue \\ Cambridge, MA 02138 \\ September 2011
}

We thank Enrique Alberola, Charles Engel, Kristin Forbes, Marcel Fratzscher, Simon Gilchrist, Gita Gopinath, Galina Hale, Laura Jones Dooley, Gian Maria Milesi-Ferretti, Kenneth Rogoff, Sergio Schmukler, Jeremy Stein, two anonymous referees, and participants in seminars and conferences at Bar Ilan University, the CEPR Bank Crisis Prevention and Resolution Conference in Amsterdam, the NBER Summer Institute, and the Pacific Basin Research Conference at the San Francisco Fed for helpful suggestions. Jonathan Hoddenbaugh and Konstantin Kosenko provided excellent research assistance. Benmelech is grateful for financial support from the National Science Foundation under CAREER award SES-0847392 and from the GARP Risk Management Research Program Grant. All errors are our own. The views expressed herein are those of the authors and do not necessarily reflect the views of the National Bureau of Economic Research.

NBER working papers are circulated for discussion and comment purposes. They have not been peerreviewed or been subject to the review by the NBER Board of Directors that accompanies official NBER publications.

(C) 2011 by Efraim Benmelech and Eyal Dvir. All rights reserved. Short sections of text, not to exceed two paragraphs, may be quoted without explicit permission provided that full credit, including (C notice, is given to the source. 
Does Short-Term Debt Increase Vulnerability to Crisis? Evidence from the East Asian Financial

Crisis

Efraim Benmelech and Eyal Dvir

NBER Working Paper No. 17468

September 2011

JEL No. F32,F34,G21,G32,G38

\begin{abstract}
Does short-term debt increase vulnerability to financial crisis, or does short-term debt reflect -- rather than cause -- the incipient crisis? We study the role that short-term debt played in the collapse of the East Asian financial sector in 1997-1998. We alleviate concerns about the endogeneity of short-term debt by using long-term debt obligations that matured during the crisis. We find that debt obligations issued at least three years before the crisis had a negative, albeit sometimes insignificant, effect on the probability of failure. Our results are consistent with the view that short-term debt reflects, rather than causes, distress in financial institutions.
\end{abstract}

Efraim Benmelech

Harvard University

Department of Economics

Littauer 233

Cambridge, MA 02138

and NBER

effi_benmelech@harvard.edu

Eyal Dvir

Department of Economics

Boston College

140 Commonwealth Ave

Chestnut Hill, MA 02467

dvire@bc.edu 


\section{Introduction}

The role of short-term debt in instigating financial crises is again being hotly debated. Shortterm debt arguably exposes borrowers to roll-over risk and hence can cause and amplify financial crises. In the recent crisis, the collapse of the asset-backed commercial paper market as well as the increasing role played by short-term repurchase agreements in the balance sheets of financial institutions led financial economists to point to the fragility embedded in short-term debt and rollover risk. As a result, there are calls to regulate the use of short-term debt in the financial system especially in what is now known as the shadow banking system. Likewise, in international finance there is renewed interest in the possible role of short-term debt as an indicator of vulnerability to crisis, perhaps as part of an "early warning system". 1

In contrast to this dismal view, a markedly different account of the role of short-term debt in financial crises exists in the literature, one that turns the causality from short-term debt to financial crisis on its head. According to this view, the accumulation of short-term debt may be the optimal choice for borrowers who experience a deterioration in asset quality. As Diamond and Rajan write:

Short-term debt mirrors the nature of the investment being financed and the institutional environment that enables investors to enforce repayment. It is no surprise that illiquid or poor quality investment when a bank or banking system is close to its debt capacity will result in a buildup of short-term debt. The higher likelihood of crisis stems, not from the short-term debt, but from the illiquidity and potentially low creditworthiness of the investment being financed. (Diamond and Rajan (2001a), p. 40.)

Moreover, Diamond and Rajan (2001a,b) argue that maturity mismatch may be an optimal exante capital structure for banks when they cannot commit to fully repay investors once a project has been completed. In their model the threat of a bank run embedded in short-term debt incentivizes banks to repay investors. In this setting, if the projects being financed are seen as becoming less liquid due to an adverse shock to fundamentals, banks will find it harder to secure long-term financing from investors and as a result will increase short-term borrowing. ${ }^{2}$ Short-term debt is

\footnotetext{
${ }^{1}$ For corporate finance references see: Brunnermeier and Oehmke (2010) and He and Xiong (2009), among others. For calls to regulate the use of short-term debt, see, for example, Gorton and Metrick (2010). The recent literature in international economics on short-term debt includes: Frankel and Saravelos (2010), Lane and Milesi-Ferretti (2010), and Rose and Spiegel (2010a, 2010b).

${ }^{2}$ Similarly, the models by Tirole $(2003)$ and Jeanne $(2004,2009)$ also emphasize the role of short-term financing as a discipline mechanism for borrowers.
} 
therefore a symptom of adverse economic shocks rather than a cause.

In this paper we study the role of short-term debt in the East Asian crisis of 1997-1998. Several East Asian economies funded their rapid growth with large amounts of short-term debt, leading many to argue that this phenomenon was one cause of the crisis. For example, according to Summers (2000), "Countries should reduce their vulnerabilities to liquidity/rollover risk and balance-sheet risk....Policy biases toward short-term capital need to be avoided." ${ }^{3}$ Likewise, other observers have argued that there was a self-fulfilling element to the crisis, since the accumulation of short-term debt shifted the affected economies into a danger zone where a crisis equilibrium could emerge. ${ }^{4}$ However, it is unclear whether the accumulation of short-term debt before the crisis indeed caused vulnerability or was merely a response to the weakness of the underlying economies.

Which view is closer to the facts? Was the buildup of short-term debt in East Asian economies before 1997 a cause or an effect of the incipient crisis? Our paper is the first to address this question empirically. We construct a new dataset using individual bank-level data, which includes information on banks in the five East Asian countries most affected by the crisis: Indonesia, Malaysia, the Philippines, South Korea, and Thailand. We have detailed information on these banks' debt obligations as well as on their performance during and after the crisis. We are therefore able to link, at the individual bank level, a bank's exposure to debt of different types and maturities before the crisis and its eventual success (or failure) in surviving the crisis.

Given the ambiguous direction of causality, it is essential to deal with endogeneity of short-term debt in the empirical analysis. We employ the following strategy to identify the effect of a bank's exposure to roll-over risk on its probability of failure. Instead of examining the effect of short-term obligations on bank failure, we examine whether the likelihood of a bank failure is affected by long-term obligations that become due during or immediately after the crisis. Some of these debt obligations (loans, notes,and bonds) were issued several years before the crisis, and therefore are unlikely to represent a financial policy response to deteriorating economic conditions. Yet, as the debt matures during or immediately after the crisis, it increases the bank's exposure to roll-over risk in the same way that short-term obligations do, thereby increasing the bank's vulnerability.

\footnotetext{
${ }^{3}$ Although Summers (2000) points a finger to the role of short-term debt in the crisis, he acknowledges the endogeneity of short-term debt stemming from undeveloped financial markets in emerging economies.

${ }^{4}$ Contributions espousing this view as a major or an ancillary cause of the crisis include, among others, Furman and Stiglitz (1998), Radelet and Sachs (1998), Corsetti, Pesenti, and Roubini (1999), Rodrik and Velasco (2000), Eichengreen (2004), and Calvo (2005). Obstfeld (1996) and Cole and Kehoe (2000) analyze the earlier Mexican crisis of 1994 along similar lines.
} 
Using maturing long-term debt instead of short-term debt, we are able to estimate the separate effect of pure roll-over risk on bank failure. ${ }^{5}$

We find that obligations undertaken three years or more before the onset of the crisis and that become due during the crisis have had a negative, albeit not always significant, effect on the probability of bank failure. We interpret this result as supportive of the view of short-term debt as an equilibrium response to worsening asset quality. Our results indicate that the issuance of a debt obligation before 1995 that was scheduled to mature during the crisis years not only did not predict failure but may even have predicted success - that is, that the bank would survive the crisis. These findings are consistent with Diamond and Rajan's view of the determination of short-term debt by predetermined deteriorating economic conditions. In contrast, the alternative view, which emphasizes roll-over risk, suggests that longer-term debt obligations that become due during the crisis should have increased failure rates. Our results suggest that although short-term debt was associated with failing institutions during the crisis, it is unlikely that exposure to roll-over risk was in itself the cause of bank failures.

Our paper is related to a large empirical literature on the cross-country association between the accumulation of short-term debt and the occurrence of financial crises. ${ }^{6}$ However, as Froot (2000) and Detragiache and Spilimbergo (2004) suggest, a positive and significant coefficient of short-term debt should not necessarily be interpreted as supportive of the roll-over risk view. To our knowledge, our paper is the first to address empirically the concerns about endogeneity of short-term debt in the context of financial crises. ${ }^{7}$

The rest of the paper proceeds as follows: Section 2 summarizes the two approaches to the role of short-term debt in financial crises and clarifies what predictions follow from each. Section 3 presents the construction of our data. Section 4 presents our identification strategy and estimation results. Section 5 concludes.

\footnotetext{
${ }^{5}$ Our empirical approach is similar to Almeida at al. (2010) who use long-term debt maturing during the 2007 credit crisis to identify the effect of corporate debt maturity on investment.

${ }^{6}$ The results are mixed. Radelet and Sachs (1998) and Rodrik and Velasco (2000) find that a high ratio of shortterm debt to reserves helps predict the occurrence of capital account reversals, whereas Frankel and Rose (1996) and Milesi-Ferretti and Razin (2000) find that short-term debt has no predictive power for the occurrence of currency crises. Berg and Pattillo (1999) find an effect for some East Asian countries, but not others. More recently, Jeanne (2007) finds that short-term debt has predictive power for currency crises but not for capital account reversals.

${ }^{7}$ Related papers that employ micro-level data include Eichengreen and Mody (2000), who use data on individual international bank loans to examine the pricing of risk, and Schmukler and Vesperoni (2006), who use firm balance sheets to detect the effect of financial liberalization on debt maturity.
} 


\section{Short-Term Debt and Bank Failure: Theoretical Framework}

In this section we describe the two approaches linking short-term debt to bank failure. According to the first approach, taking on short-term debt increases a bank's exposure to a run, and the bank is therefore more likely to fail. The second approach emphasizes that short-term borrowing is endogenous and is potentially the only financing option available for lower-quality banks. Therefore, the likelihood of failure is not necessarily driven by short-term debt itself but rather is a consequence of the bank's underlying economic conditions.

\subsection{Short-Term Debt and Vulnerability to Financial Crises}

The first approach is well illustrated in Chang and Velasco (2001). They argue that in a Diamond and Dybvig (1983) framework, early withdrawals by depositors create a role for foreign borrowing: the bank will optimally use foreign loans to repay impatient depositors. Of course, the bank may be subject to a run: if all depositors demand payment at date 1, the bank may fail. ${ }^{8}$ The exact conditions under which this happens, however, depend on the extent of the bank's commitment to foreign creditors. If the bank can commit to pay foreign creditors under any circumstance, it can be sure to have access to new loans and will fail only if it cannot raise enough funds through new foreign borrowing and asset sales. In the more common case where the bank cannot commit to pay all of its foreign creditors, however, the bank's "run zone" will be larger - it will become more illiquid and therefore more susceptible to failure in a "run equilibrium." This is due to the failure of coordination among foreign creditors, much as such failure can occur among depositors. Foreign creditors may refuse to extend new loans (in effect reducing ex post the bank's line of credit to zero) or may even recall existing loans. Chang and Velasco (2001) emphasize that such behavior by foreign creditors may instigate a run where none would otherwise have occurred. In particular, consider the case of short-term debt: if foreign creditors panic, they may refuse to roll over this debt, as well as to extend new loans to cover withdrawals by depositors. This behavior will cause a run by depositors even if they would not otherwise have run on the bank. If that happens, the bank will need to pay all its depositors and short-term creditors using proceeds from the liquidation of assets. Borrowing short-term then clearly renders the bank's more susceptible to runs. This leads to the following prediction:

\footnotetext{
${ }^{8}$ Chang and Velasco (2000) offer an extension of this model in which debt maturity and the term structure are jointly determined. We do not test for interest rate effects in this paper due to lack of data.
} 
Prediction 1: Any debt obligation, regardless of original maturity, has a positive effect on the probability of failure when it becomes due.

\subsection{The Endogeneity of Short-Term Debt}

Diamond and Rajan (2001a) have a different approach to short-term debt. In their model, an investment project derives much of its value from the human capital of the project's entrepreneur. This creates a potential holdup problem for investors, which is solved by financing the project through a bank. In particular, the bank can replace the entrepreneur, which will reduce the project's value but not make it worthless. In essence, investors employ the bank as their agent to negotiate effectively with the project's entrepreneur and in this way collect payment. The bank, in turn, may extract a rent in return for these intermediation and collection skills. In bargaining with investors, the bank extract a fraction of the collected payment.

Diamond and Rajan (2001a) show that a system of demand deposits is an effective disciplining device. Any attempt by the bank to re-negotiate its obligation to the depositors will result in a run. In such a case, depositors will seize the loan contract and negotiate directly with the entrepreneur. Faced with the loss of its intermediation rent, the bank will not try to re-negotiate and will transfer all collected payments to the depositors.

In their model banks will usually be financed by a mix of demand deposits and long-term capital. Although long-term capital can sometimes prevent a run and allow the bank to remain open, longterm investors may be forced to absorb losses stemming from a decline in the bank's asset quality while depositors run on the bank's assets. Banks that are perceived as having less attractive assets will therefore find it hard to obtain long-term investor capital, relying instead more on short-term loans that can be recouped more easily if the bank's position deteriorates. These banks naturally will be more likely to fail eventually due to the lower quality, or greater illiquidity, of their assets but not because of short-term debt. This leads to the following prediction:

Prediction 1A: Original maturity matters. Banks with relatively more short-term debt are

more likely to fail, because their underlying asset quality is the reason for relying on short-term financing. However, banks with relatively more long-term debt will be less likely to fail. 


\section{Data and Summary Statistics}

Our dataset is at the individual bank level, covering financial institutions that were in operation in the years leading to the crisis in the five affected East Asian countries: Indonesia, Malaysia, the Philippines, South Korea, and Thailand. We start by extracting financial data (assets, debt, deposits, profitability, etc.) from Bankscope, a publicly available database that covers 28,200 banks worldwide. We limit our search to data pertaining to banks located in the five relevant countries for the years 1992-2002. There are 415 banks in the database that meet these criteria. ${ }^{9}$ The distribution of the banks across the five countries is as follows: 112 in Indonesia, 97 in Malaysia, 64 in the Philippines, 76 in South Korea, and 66 in Thailand. Next, for each bank in our dataset, we collect information as to whether that bank survived the crisis or failed. We use of several sources to collect this information, which we employ in the following order:

1. First, we perform an Internet search using the publicly available archives of a daily industry newsletter. The Asia-Pacific edition of the newsletter - Troubled Company Reporter - has been appearing continuously since February 1998. ${ }^{10}$ The fully searchable newsletter reports events such as profit and loss announcements, negotiations of rescheduling of debt, government actions. and more.

2. Second, we cross-reference any information found on the Website with other available sources. A number of researchers provide partial lists of bank outcomes. In particular, Arena (2005) provides a relatively comprehensive list of failed banks during the East Asian crises, covering all five countries. Kim (1999) reports detailed outcome information on most of the Korean banking industry. Chou (1999) lists Indonesian banks that were placed under government control, and Kawai and Takayasu (1999) provide a detailed history of bank outcomes in Thailand.

3. Third, we perform a general Internet search for each of the banks in our Bankscope dataset. This additional step is especially useful for surviving banks since these banks' Websites often would include detailed corporate histories, such as dates of mergers and acquisitions, as well as name changes if they occurred

\footnotetext{
${ }^{9}$ We construct our dataset using the separate Bankscope data for each of these years, thus avoiding survival bias.

${ }^{10}$ The newsletter archives are available at: http://www.bankrupt.com/TCRAP_Public/index.html.
} 
We then classify a bank as failed if it meets at least one of the following conditions in any year from 1997 to 2002 :

1. The bank was closed down by the government or one of its agencies.

2. The bank was taken over by the government or one of its agencies, typically by means of significant recapitalization, which gives the government or its agency effective control of the bank.

3. The bank was forced by the government or one of its agencies to merge into another bank or a consortium of banks - that is, recapitalization was effectively done by other banks instead of the government or its agency.

For each of the failed banks we record the year of failure based on the information we collected. This methodology of classifying failed banks is similar to the approach used by Arena (2005). Note that some banks were ordered initially to cease operations, only later to be subjected to one of the above resolution methods. If we cannot ascertain which method was finally chosen but are certain that it did not survive, we list the bank as "frozen." We are careful not to count consolidations with other banks as failures unless we can ascertain that the consolidation was done under government instructions. Our empirical results (see Section 4 and Appendix, Table A1) do not depend on the exact definition of failure: if we drop in turn banks that meet any one condition of failure, our regressions yield qualitatively similar results, regardless of which group of banks was dropped.

We are able to classify 359 cases out of the 415 banks in our initial Bankscope dataset. The distribution of these 359 banks is as follows: 109 banks in Indonesia, 91 in Malaysia, 53 in the Philippines, 58 in South Korea, and 48 banks in Thailand, with a total of 2,488 bank-year observations. The remaining 56 banks were dropped from the dataset. ${ }^{11}$ To our list of 359 banks, we add 52 banks for which we have been able to find outcome information but are not in the Bankscope database. Our final data set includes 411 banks, out of which 212 banks meet at least one of our definitions for failure. ${ }^{12}$ Table 1 reports the distribution of bank failures across countries and along the years in our sample. Korea and Thailand were hit especially hard, with $82 \%$ and $74 \%$, respectively, of the sample banks located in these countries failing by 2002. Thailand experienced

\footnotetext{
${ }^{11}$ Most of observations we drop are not commercial banks but rather other types of financial institutions.

${ }^{12}$ Of these, 12 banks can be classified as government-sponsored. Dropping these banks as well has no effect on our results.
} 
a large number of failures in 1997 that subsided in later years (with a later peak in 2001), whereas in Korea the crisis evolved more gradually, reaching its peak (in terms of bank failures) in 1999, and gradually subsiding afterward. Indonesia and Malaysia, both with $44 \%$ of their banks failing by 2002, exhibit a pattern similar to Korea, with the crisis reaching its peak in 1999 and 2000, respectively. The Philippines is the least affected country, with a sample failure rate of $18 \%$.

We augment our dataset using information on debt obligations issued by banks in the five relevant countries. Our data is taken from the SDC Platinum database, covering all debt issues in these countries from 1976 to 2002. SDC Platinum is a comprehensive international dataset that provides information about every debt obligation issued anywhere in the world, including (depending on availability) the type of debt (bank loan, bond, note, fixed-term deposit, etc.) and the terms of the debt obligation (original maturity, principal amount, interest rate, currency). Matching the data from SDC Platinum with our survival data, we end up with 208 banks, for which we have 1,839 debt issues.

In matching the two datasets we allow for the common occurrence of banks changing their names following a merger or an acquisition. The resulting dataset reflects the state of affairs in 1997 with respect to bank names and affiliations, so that debt obligations that were taken by a bank which was then acquired before 1997 are reflected in our dataset as if they were taken by the acquiring bank. Given the comprehensive coverage of SDC Platinum, we can classify the banks for which information on debt obligations is not available as banks that did not take on foreign debt during our sample period.

\subsection{Debt Issuance and Maturity}

Table 2 reports summary statistics of debt obligations that were taken by banks in our dataset. The vast majority of debt is denominated in foreign currency, of which by far the most prevalent is the U.S. dollar. Of all debt obligations issued by banks that are included in our dataset, $73 \%$ are denominated in dollars. The maturity structure of those obligations are quite similar probably because that banks in all five countries were competing to borrow funds in similar capital markets. Given the cross-country differences in timing and severity of the crisis shown earlier in Table 2, it is interesting that banks across the region seem to have been quite similarly exposed to short-term debt.

As a first cut of the data, Table 3 presents the differences in the original debt maturity between 
failed and non-failed banks in our dataset. As Panel A demonstrates, failed banks issue, on average, debt of slightly shorter maturity, but the difference in means between failed and non-failed banks is negligible and statistically insignificant. The maturity distribution of debt issued by failed banks is very similar to that of non-failed banks. The only difference we detect between the distributions of maturity is in the extreme right tail: the maximum maturity of an obligation of a failed bank in our dataset is 15 years, while the maximum maturity of an obligation of a non-failed bank is 25 years.

Panel B of Table 3 explores further the maturity distributions of the two groups, comparing debt maturity by year of issue. Comparing debt maturity of the two groups of banks in the decade 1980-1990, we find that failed banks issued debt with longer maturity compared to non-failed banks. When we focus on obligations issued closer to the crisis, however, we find that failed banks issue debt of shorter maturities. It is interesting to note that the average debt maturity of both groups declined in the 1990s relative to the 1980s, potentially reflecting lenders' concerns about East Asian economies. During the 1990s debt maturities of banks that eventually failed during the East Asian crisis declined more relative to those that did not fail.

The results in Panel B are consistent with both views of short-term debt. On the one hand, borrowing more short-term debt in the years before the crises could have made the banks that eventually failed more vulnerable to roll-over risk and financial crisis. On the other hand, adverse changes to asset quality or loan repayment schedules in these banks, which would increase their likelihood of failing, could have led to greater reliance on short-term debt. ${ }^{13}$ After 1997, however, banks that eventually survived prolonged their debt maturity significantly, whereas those that eventually failed relied on debt of shorter maturity. This suggests that even in the immediate aftermath of the crisis, market participants could distinguish between banks of varying quality.

We next move to analyze the determinants of the maturity of the debt obligations in our sample. We focus on foreign-currency-denominated debt - debt issued in a currency other than the bank's domestic currency. ${ }^{14}$ The first two columns of Table 4, present the results of OLS regressions in which debt maturity (in years) is regressed on a dummy variable that takes the value of one if the issuing bank has failed, and zero otherwise. In the second column we add a dummy variable that takes the value of one for debt obligations rated by Standard \& Poor's (S\&P). In both regressions

\footnotetext{
${ }^{13}$ In the case of South Korea, Noland (2005) ascribes Korean banks' increasing reliance on short-term debt in the 1990s to the Korean government's policy of discouraging long-term debt.

${ }^{14}$ Appendix Table A3 provides analysis that is based on both foreign- and domestic-currency-denominated debt.
} 
we include year and country fixed effects, as well as an interaction term of year with the failure dummy. Standard errors are clustered by country in all the regressions. As the regression results demonstrate, debt obligations issued by failed banks were of shorter maturity, approximately 1.6 years lower on average relative to obligations taken by banks that survived the crisis. Adding the bond rating dummy in the second regression adds some explanatory power - $\mathrm{S} \& \mathrm{P}$ credit rating is associated with a significantly longer bond maturity - but does not change the quantitative effect. The next two columns present the results of probit regressions (marginal effects are reported), where the dependent variable is the probability that maturity is equal to or less than either one year (column 3) or two years (column 4). We again include year and country fixed effects, as well as an interaction term as before. The probit results are consistent with the OLS regressions: the probability of a failed bank issuing debt with maturity that does not exceed one year is $28 \%$ higher relative to a surviving bank. Likewise, failed banks are $40 \%$ more likely to issue short-term debt obligations with a maturity up to two years compared to surviving banks.

\subsection{Characteristics of East Asian Banks}

We aggregate up our debt issuance data to the bank level. For each bank in our dataset, and for each year from 1997 to 2002, we calculate the total debt previously issued by the bank that matures in that year. ${ }^{15}$ We then further separate the maturing debt by year of origination. Thus we identify the amount of debt of bank $i$ that is scheduled to mature in year $t$, and that was originated in years 1996, 1995, 1994, 1993, and before. This method creates a snapshot of the bank's exposure to rollover risk at any given year, while keeping track of the origination date of the obligations involved. Our main regression specification examines the effect, for each bank-year pair, of the amount of maturing debt on the probability of failure in the given year, controlling for bank's characteristics.

Table 5 presents summary statistics for size, profitability, debt ratio (defined as the sum of bank's debt obligations divided by its assets), and deposit ratio (defined as the sum of demand deposits divided by its assets) at the bank-year level. There are 111 bank-year observations that correspond to a bank failure in the given year and 1,314 bank-years observations without a failure. ${ }^{16}$ Failed banks are much larger $(\$ 12,234$ million compared to $\$ 4,668$ million) and less profitable (return of assets of $-8.2 \%$ compared to $-0.5 \%$ ) relative to banks that did not fail. The debt ratio of failed banks

\footnotetext{
${ }^{15}$ To focus on the East Asian crisis, we include only the years from 1997 . We do not observe any bank failures before 1997 in our sample.

${ }^{16}$ Obviously, we do not include banks that have already failed before the given year.
} 
is, as expected, significantly higher than that of non-failed banks (99.7\% compared to $86.8 \%$ ), but there is no significant difference in the deposits ratio between those that fail and banks that did not fail.

Table 6 compares bank-year pairs only for those banks that are actually exposed to roll-over risk - that is, have at least some maturing debt. A large share of the failed banks (43.9\%) were exposed to roll-over risk in the year of failure. In contrast, only a small fraction (9.8\%) of the banks that did not fail were exposed to roll-over risk. As before, we find size and profitability differences between failed and non-failed banks: failed banks are significantly larger and less profitable. In this subsample, however, failed banks are more exposed to maturing debt that was issued closer to the crisis years. The difference appears particularly stark in the last column, which shows that maturing debt originating before 1993 constituted only $1.7 \%$ of exposure for failed banks, compared with $6.4 \%$ for banks that did not fail. By excluding more recent debt issues, we are able to measure banks' exposure to roll-over risk that is due to long-term obligations issued years before the crisis. This is our key identification strategy in the empirical analysis that we discuss more in the next section.

\section{Identification and Empirical Analysis}

We use maturing debt obligations that originated as long-term liabilities to identify the effect of exposure to roll-over risk on the probability of bank failure. Our identifying assumption is that the debt was issued before the arrival of adverse information owing to the deterioration in the quality of the bank and the economy associated with the crisis. Yet, given that the debt happens to mature during the crisis, it increases the bank's exposure to roll-over risk - similar to any other maturing short-term obligation. If exposure to roll-over risk is a leading cause of bank failure during the crisis, then having more maturing long-term debt should increase the probability of failure as predicted by Chang and Velasco (2001). If, on the other hand, weak bank fundamentals were the leading cause of the failure, as Diamond and Rajan (2001a) argue, then having more long-term debt would indicate that the bank has had less need to borrow short-term, which could be due to its fundamentals being perceived as relatively strong. This should be reflected in our regressions as a negative effect of maturing long-term debt on the probability of bank failure.

A few caveats are in order. First, our method excludes the effects of short-term debt by con- 
struction. Therefore we cannot determine whether there has been a roll-over risk effect associated somehow only with short-term debt. Second, our data do not account for such very short-term obligations as commercial paper and repo, but the markets for these very short-term obligations may be more prone to "bank runs" due to strategic externalities and sun spots than to pure roll-over risk.

\subsection{Baseline Regressions}

We define an indicator variable that takes on the value of one when a bank $i$ fails at year $t$ and zero otherwise, and estimate different variants of the following specification:

$$
\operatorname{Pr}\left(\text { Failure }_{i, t}=1 \mid \text { size }_{i, t}, \text { profitability }_{i, t}, \Sigma_{\tau=t}^{T} \operatorname{debt}_{i, \tau}^{Y E A R}, \operatorname{debt}_{i, t}^{Y E A R}\right)=\int_{-\infty}^{z} \phi(k) d k,
$$

where size $_{i, t}$ is the natural logarithm of bank $i$ 's book value of assets at year $t$, and profitability $i, t$ is defined as bank $i$ 's profitability (as measured by its return on assets). The variable $\Sigma_{\tau=t}^{T} d e b t_{i, \tau}^{Y E A R}$ captures the overall outstanding debt of bank $i$ in year $t$ that originates in a particular year as a fraction of the bank's assets in year $t$. This is given by the sum of all debt (as fraction of assets) scheduled to mature in year $t$ or at any future year. In other words, this variable controls for the bank's leverage in year $t$.

$d e b t_{i, t}^{Y E A R}$ denotes bank $i$ 's maturing debt obligations in year $t$ (as a fraction of overall assets) that originate before the specified year. For example, the variable $d e b t_{i, t}^{97}$ denotes debt obligations that originate at any time before 1997 and mature in year $t$ (as a fraction of bank $i$ 's overall assets in year $t$ ), therefore including both short- and long-term debt. ${ }^{17}$ In contrast, the variable debt $t_{i, t}^{94}$ includes only maturing debt obligations that originate at any time before 1994 (excluding shortterm debt). Finally, $\phi(k)$ is the standard normal density, and $z=\beta_{1}$ size $_{i, t}+\beta_{2}$ profitability $_{i, t}+$ $\delta \Sigma_{\tau=t}^{T} d e b t_{i, \tau}^{Y E A R}+\gamma d e b t_{i, t}^{Y E A R}$. We estimate regression (1) through probit.

Table 7 reports different specifications of regression (1) and displays marginal coefficients (at the mean) for the explanatory variables. The displayed t-statistics are calculated using standard errors clustered by country. Throughout the table, each column reports a different debt variable used in the regression, ranging from $d e b t_{i, t}^{97}$ in the first column to $d e b t_{i, t}^{93}$ in the last column (with the corresponding measures of outstanding debt). Panel A presents results without fixed effects. As the table shows, both size and profitability are highly significant determinants of bank failure.

\footnotetext{
${ }^{17}$ Recall that our regressions include only foreign-currency-denominated debt.
} 
As expected, less profitable banks are more likely to fail. Moreover, larger banks are more likely to fail during and immediately after the crisis, a result that is robust in all specifications. Finally, total debt to assets has a positive effect on the probability of failure.

Our main empirical finding lies in the coefficients of the maturing debt variables. These coefficients exhibit a clear difference between the effect of obligations of different original maturities. As we move from left to right, the regressions portrayed in Table 7 include more obligations that originated as long-term debt. As the table illustrates, only when we include all debt issued before 1997 do we get a positive and significant effect on the probability of failure. In contrast, debt that was issued in 1996 or before either does not have a statistically significant effect on the probability of bank failure in this specification or actually has a negative and significant effect. Economically, these effects are substantial. Panel B, which reports results from regressions that include country and year fixed effects, presents similar patterns. We find that the coefficients of size are now smaller and less significant, whereas the coefficients of profitability are almost unchanged. Most important, the effect of maturing debt that includes relatively short-term debt is still positive, yet it is smaller and no longer statistically significant. The coefficients on longer-term maturing debt (i.e., debt issued before 1996) retain their negative signs and statistical significance (for debt issued before 1995). The effects are economically significant as well, with a one standard deviation increase in maturing debt issued before 1994, for example, lowering the probability of bank failure by 115 basis points, or more than $18 \%$ relative to the mean.

Given our identification strategy, our findings in both panels of Table 7 indicate that roll-over risk in itself fails to explain bank failure. Indeed, we find that in most specifications maturing long-term debt negatively affects the probability of failure, a result completely at odds with the notion that pure roll-over risk causes bank failure. The assertion that any maturing debt obligation, regardless of original maturity, has a positive effect on the probability of failure (Prediction 1) fails to hold in the data. In contrast, Prediction 1A seems to fit the data better. We find that maturing debt that originated as longer-term obligations reduces the probability of failure, as would be the case if indeed weaker banks could only get short-term financing. ${ }^{18}$

We next check that our results are not driven by the functional form of the probit regression

\footnotetext{
${ }^{18}$ Note that the inclusion of country and year fixed effects allows us to control for differences in the reaction of governments and societies across East Asia to the severe crisis. These differences are important in accounting for patterns of bank failure, as shown by the almost doubling of the pseudo- $R^{2}$ from 0.10 to 0.19 . However, since our definition of maturing debt takes into account only debt that originates before the crisis, it is unaffected by differences in post-crisis reaction.
} 
methodology. We therefore also perform survival analysis on which we examine the effect of the explanatory variables on the failure hazard function $\lambda(t)$ - that is, the likelihood of failure as a function of time passed since year 0, which in our case is the year 1996. We estimate the regressions using the Cox proportional hazard model - a semi-parametric method and therefore less restrictive than fully parametric estimation. In these hazard models we study banks during the period 1997-2002 instead of bank-year pairs as before. ${ }^{19}$ Our results are broadly similar, however, with differences mainly in the statistical significance of the various coefficients, but with remarkably close estimates of economic significance. The results are reported in Table 8. As Panel A reports, without fixed effects, maturing debt that includes short-term debt has a significantly positive effect on the likelihood of a bank failure, whereas maturing debt that does not include these short-term obligations has a negative effect, though not always significant. In Panel B, where country and year fixed effects are included, we find again that the coefficients for maturing debt which includes short-term debt are smaller and in some cases less significant, whereas the coefficients on debt issued before 1995 or 1994 are still statistically significant.

We also perform additional robustness tests that pertains to additional control variables and estimation techniques. In Table 9 we use the same probit specification as in regression (1) with two additional control variables: (i) debt-asset ratio, and (ii) deposit-asset ratio. These variables arguably control better for the financial position of the bank and the strength of its balance sheet. Because the information on these variables is not available for a small number of banks, the sample size is reduced from 1,776 (in Table 8) to 1,731. As Table 9 shows, our results are robust to the inclusion of these variables and maintain their statistical significance as well as their economic magnitude. Similar results are obtained when we run the regressions using the Cox proportional hazard model (Table 10). Adding controls for the bank debt-asset ratio and deposit-asset ratio lead to similar estimates to those found in Tables 8 and 9 .

Finally, we also estimate complementary log-log models of regression (1). Unlike probit, the complementary log-log function is asymmetrical and allows the cumulative distribution function to be an extreme value distribution. Table 11 present the results from these estimations. ${ }^{20}$ As the table shows, we obtain similar results to those found in the probit and hazard regressions.

\footnotetext{
${ }^{19}$ The major difference between the methods is in censoring: when estimating the likelihood of failure via probit, we do not drop any post-failure observations, since they may contain useful information pertaining to the timing of failure. Survival analysis, however, does require us to drop these observations.

${ }^{20}$ We use Stata cloglog procedure to estimate the complementary log-log regressions.
} 
In additional results reported in Appendix A, we use alternative definitions for bank failure (Table A1), control for money-market to asset ratio (Table A2), and include domestic debt in addition to foreign debt (Table A3). Table A1 reports results from a complementary log-log regression where we exclude banks that merged with others. As Table A1 shows, the results are very similar to those found in Table $11 .^{21}$ Table A2 reports results of additional complementary log-log regressions, now including a money-market control variable, defined as the sum of money-market securities (such as CDs and commercial paper) divided by total bank assets. ${ }^{22}$ As Table A2 shows, including this variable does not change our results, with one exception: maturing debt that originated before 1996 now has a significant negative effect, whereas in the main regressions it is insignificant. In Table A3 we re-calculate the debt variables (debt maturing this year and debt outstanding) to include all debt, domestic as well as foreign. The results are, again, very similar to those based on foreign debt.

\section{Conclusion}

We study the role that short-term debt plays in financial crises. The financial crisis of 20072009 led many to believe that short-term debt leads to financial fragility and roll-over risk. As a result, there are calls to regulate the use of short-term debt in the financial system - especially in non traditional financial institutions. However, even though short-term debt arguably exposes borrowers to roll-over risk and hence can cause amplify financial distress, it is endogenous and is likely to be a symptom rather than a cause of distress. Our empirical analysis shows that shortterm debt maturing during the 1997-1998 financial crisis did not cause bank failures even in the most adversely affected economies. Our evidence suggests that short-term debt was a symptom of weak financial institutions rather than the reason for their demise.

\footnotetext{
${ }^{21}$ We are unable to further disaggregate the definition of a failure as it leads to very little variation in the dependent variable.

${ }^{22}$ Information on money-market securities is not available for many banks, so we do not include it as an explanatory variable in our main specifications.
} 


\section{References}

Acharya, V.V., Gale, D., Yorulmazer, T., 2009. Roll risk and market freezes. Working paper, New York University.

Almeida, H., Campello, M., Laranjeira, B., Weisbenner, S., 2010. Corporate debt maturity and the real effects of the 2007 credit crisis. Working Paper, University of Illinois.

Arena, M., 2005. Bank failures and bank fundamentals: a comparative analysis of Latin America and East Asia during the nineties using bank-level data. Bank of Canada Working Paper No. 2005-19.

Berg, A., Pattillo, C., 1999. What caused the Asian crises: an early warning system approach. Economic Notes by Banca Monte dei Paschi di Siena 28, 285334. Brunnermeier, M., Oehmke, M., 2010. The maturity rat race. Working Paper, Princeton University.

Calvo, G., 2005. Emerging Capital Markets in Turmoil: Bad Luck or Bad Policy? MIT Press, Cambridge, MA.

Chang, R., Velasco, A., 2000. Banks, debt maturity and financial crises. Journal of International Economics 51, 169194.

Chang, R., Velasco, A., 2001. A model of financial crises in emerging markets. Quarterly Journal of Economics 116, 489517.

Chou, C., 1999. Indonesian banks: survival of the fittest, in: Rising to the Challenge in Asia: A Study of Financial Markets, Indonesia. Asian Development Bank, Manila.

Cole, H.L., Kehoe, T.J., 2000. Self-fulfilling debt crises. Review of Economic Studies 67, 91116.

Corsetti, G., Pesenti, P., Roubini, N., 1999. What caused the Asian currency and financial crisis? Japan and the World Economy 11, 305373.

Detragiache, E., Spilimbergo, A., 2004. Empirical models of short-term debt and crises: do they test the creditor run hypothesis? European Economic Review 48, 379389.

Diamond, D.W., Dybvig, P., 1983. Bank runs, deposit insurance, and liquidity. Journal of Political Economy 91, 401419.

Diamond, D.W., Rajan, R.G., 2001a. Banks, short-term debt and financial crises: theory, policy implications and applications. Carnegie-Rochester Conference Series on Public Policy 54, 3771.

Diamond, D.W., Rajan, R.G., 2001b. Liquidity risk, liquidity creation and financial fragility: a theory of banking. Journal of Political Economy 109, 287327.

Eichengreen, B., 2004. Capital Flows and Crises. MIT Press, Cambridge.

Eichengreen, B., Mody, A., 2000. Lending booms, reserves and the sustainability of short- term debt: inferences from the pricing of syndicated bank loans. Journal of Development Economics 63, 544.

Frankel, J.A., Rose, A.K., 1996. Currency crashes in emerging markets: an empirical treatment. Journal of International Economics 41, 351366.

Frankel, J.A., Saravelos, G., 2010. Are leading indicators of financial crises useful for assessing country vulnerability? Evidence from the 200809 global crisis. NBER Working Papers 16047.

Froot, K.A., 2000. Comment, in: Pleskovic, B., Stiglitz, J.E. (Eds.), Proceedings of the 1999 Annual World Bank Conference on Development Economics. World Bank, Washington, DC. 
Furman, J., Stiglitz, J.E., 1998. Economic crises: evidence and insights from East Asia. Brookings Papers on Economic Activity No. 2, 1135.

Gorton, G.B., Metrick, A., 2010. Regulating the shadow banking system. Working Paper, Yale University.

He Z., Xiong W., 2009. Liquidity and short-term debt crises. Working Paper, Princeton University. Jeanne, O., 2004. Debt maturity and the international financial architecture. IMF Working Paper 137.

Jeanne, O., 2007. International reserves in emerging market countries: too much of a good thing? Brookings Papers on Economic Activity No. 2, 155.

Jeanne, O., 2009. Debt maturity and the international financial architecture. American Economic Review 99, 21352148.

Kawai, M., Takayasu K., 1999. The economic crisis and banking sector restructuring in Thailand, in: Rising to the Challenge in Asia: A Study of Financial Markets, Thailand. Asian Development Bank, Manila.

Kim, D., 1999. Bank restructuring in Korea, in: BIS Policy Papers No. 6: Bank Restructuring in Practice. Bank of International Settlements, Basel.

Lane, P.R., Milesi-Ferretti, G.M., 2010. The cross-country incidence of the global crisis. Institute for International Integration Studies Discussion Paper No. 333.

Milesi-Ferretti, G.M., Razin, A., 2000. Current-account reversals and currency crises: empirical regularities, in: Krugman, P. (Ed.), Currency Crises. University of Chicago Press, Chicago.

Noland, M., 2005. South Koreas experience with international capital flows. Institute of International Economics Working Paper 05-4.

Obstfeld, M., 1996. Models of currency crises with self-fulfilling features. European Economic Review 40, 10371047.

Radelet, S., Sachs, J.D., 1998. The East Asian financial crisis: diagnosis, remedies, prospects. Brookings Papers on Economic Activity No. 1, 190.

Rodrik, D., Velasco, A., 2000. Short-term capital flows, in: Pleskovic, B., Stiglitz, J.E. (Eds.), Proceedings of the 1999 Annual World Bank Conference on Development Economics. World Bank, Washington, DC.

Rose, A.K., Spiegel, M.M., 2010. Cross-country causes and consequences of the 2008 crisis: early warning. Global Journal of Economics, forthcoming.

Rose, A.K., Spiegel, M.M., 2010. The causes and consequences of the 2008 crisis: an update. NBER Working Paper No. 16243.

Schmukler, S.L., Vesperoni, E., 2006. Financial globalization and debt maturity in emerging economies. Journal of Development Economics 79, 183207.

Summers, L., 2000. International financial crises: causes, prevention, and cures. American Economic Review 90, 116.

Tirole, J., 2003. Inefficient foreign borrowing: a dual- and common-agency perspective. American Economic Review 93, 16781702. 


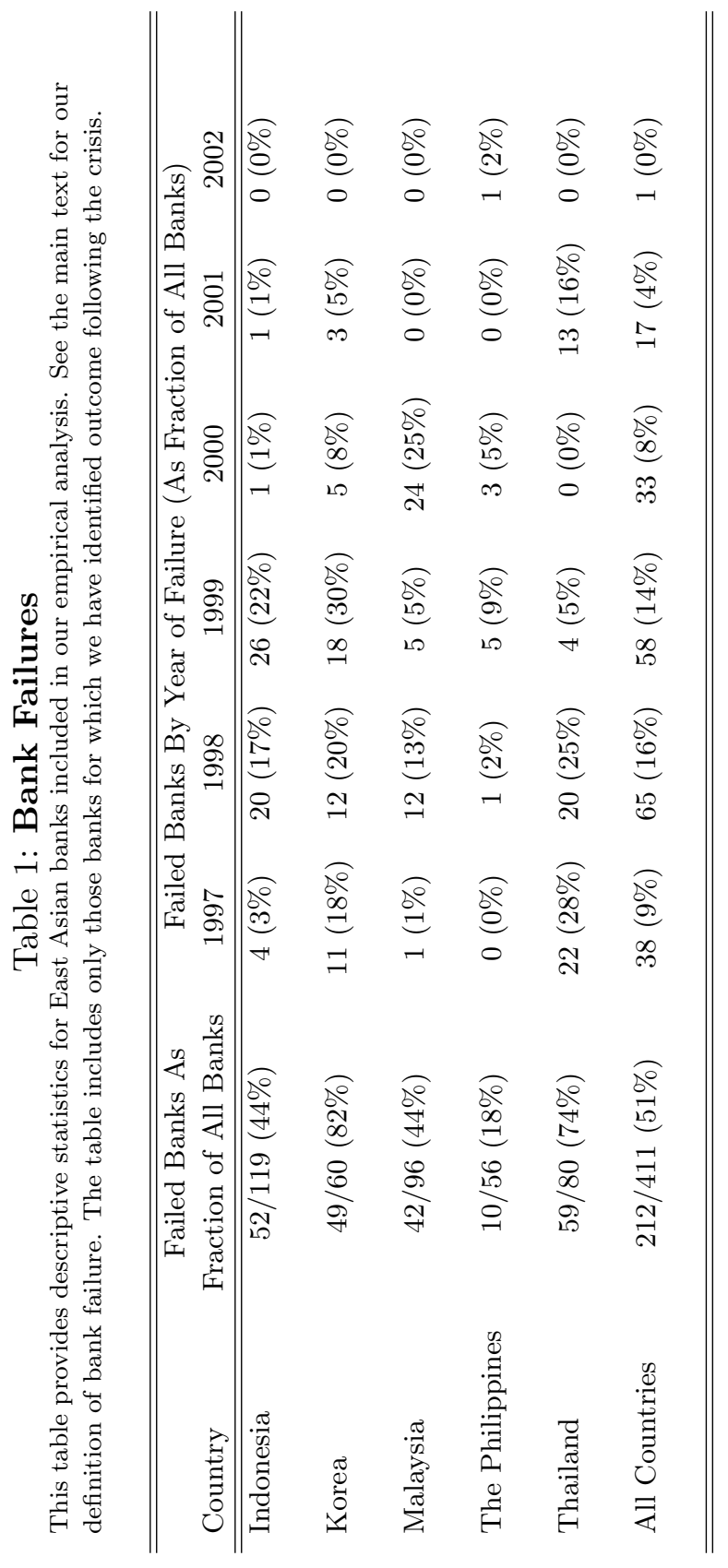




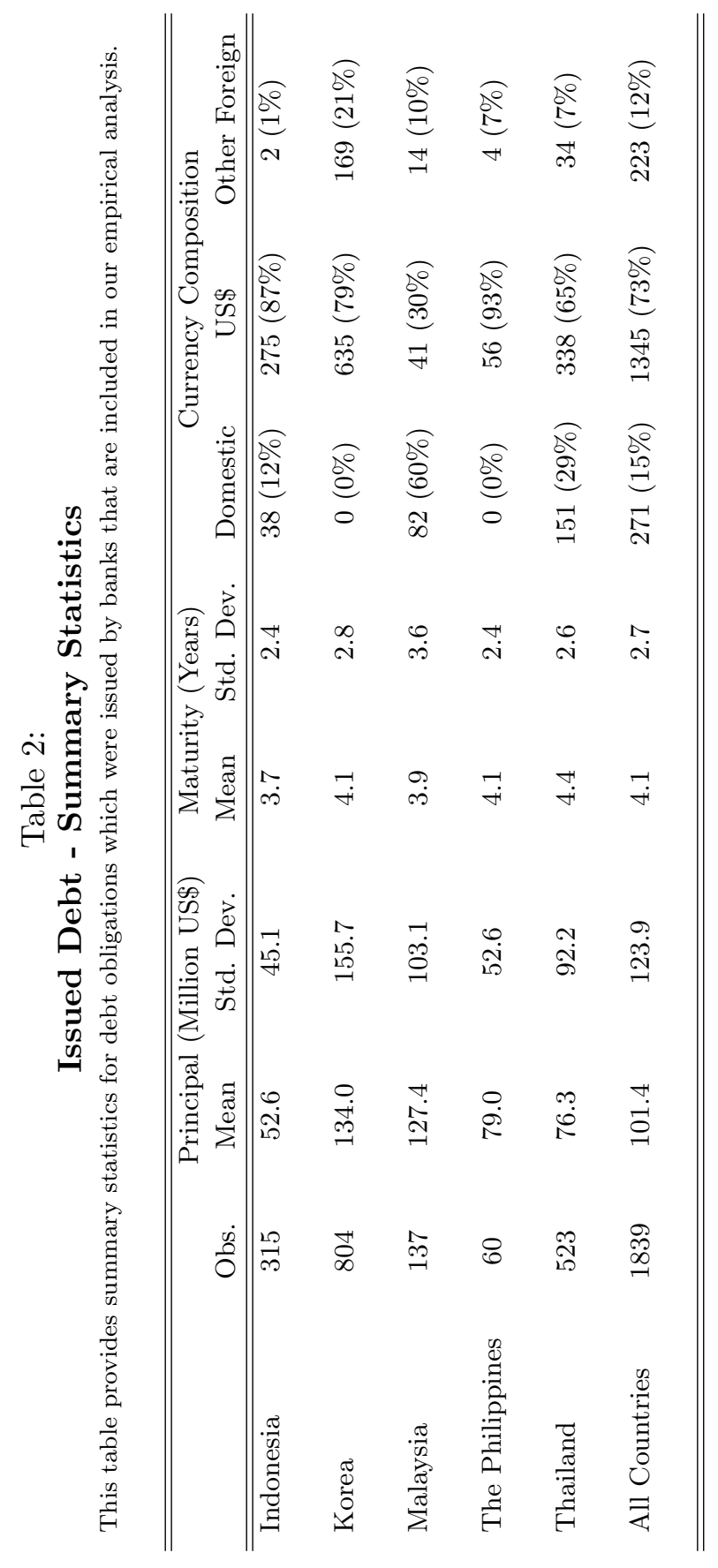




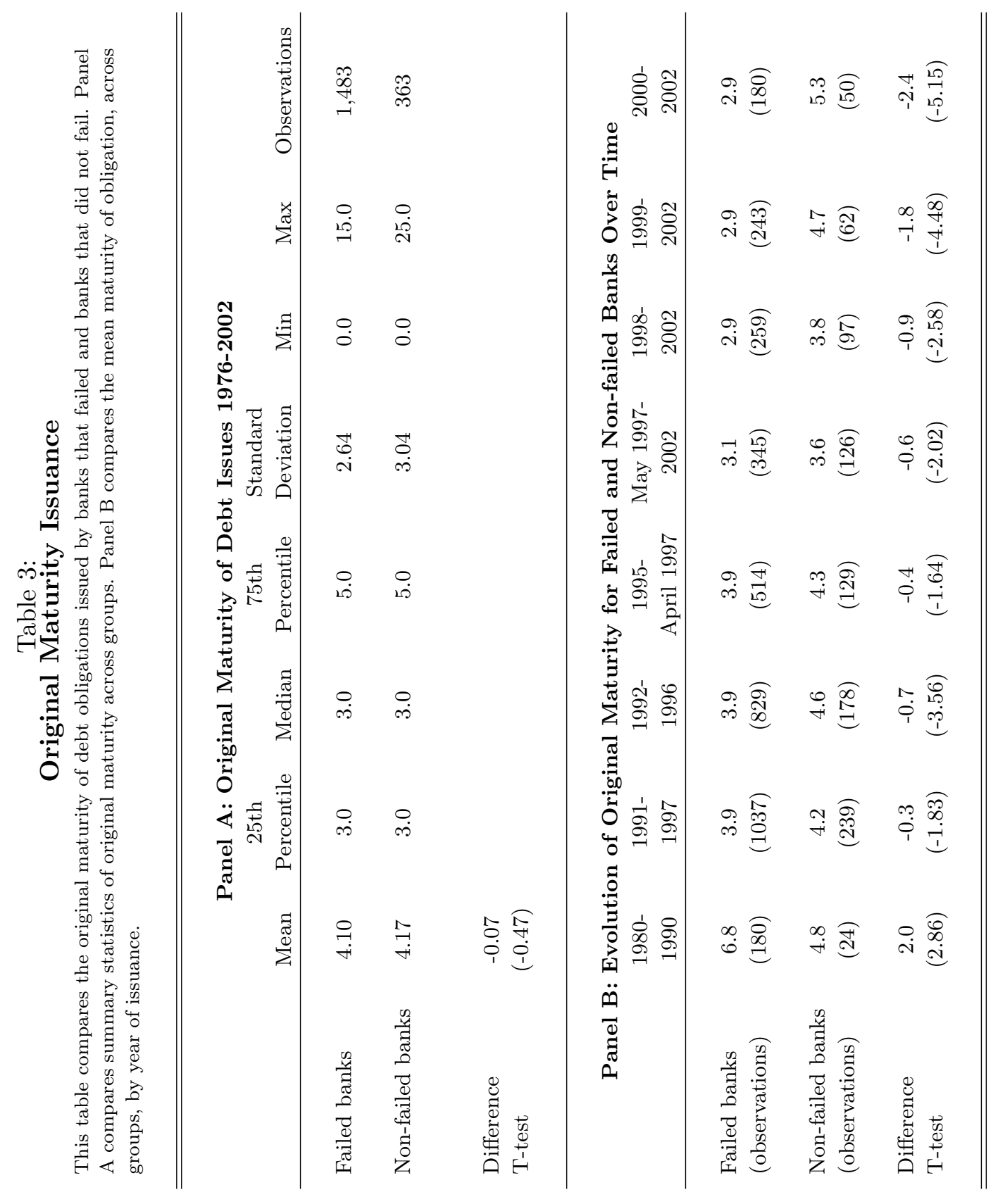


Table 4:

\section{Original Maturity Regressions}

The regressions presented in this table include only foreign-currency-denominated debt obligations issued by banks in our dataset. Failed equals 1 if the issuing bank has met the conditions for failure in any of the years 1997-2002. Rated equals 1 if the debt obligation received a Standard \& Poor's rating. Estimation was performed by OLS and probit (marginal effects reported), as appropriate. $t$-statistics, calculated using standard- errors that are clustered by year, are reported in parentheses. All regressions include year and country fixed effects, as well as an interaction term of year with Failed.

\begin{tabular}{lcccc}
\hline \hline \multirow{2}{*}{$\begin{array}{l}\text { Dependent } \\
\text { Variable }=\end{array}$} & Maturity & Maturity & $\operatorname{Pr}($ Maturity $\leq 1)$ & $\operatorname{Pr}($ Maturity $\leq 2)$ \\
\hline \multirow{2}{*}{ Failed } & & & & \\
& $-1.58 \mathrm{a}$ & $-1.66 \mathrm{a}$ & $0.28 \mathrm{a}$ & $0.40 \mathrm{a}$ \\
Rated & $(-7.36)$ & $(-7.20)$ & $(21.59)$ & $(26.57)$ \\
& & $1.79 \mathrm{a}$ & $-0.07 \mathrm{~b}$ & $-0.15 \mathrm{a}$ \\
Adjusted $R^{2}$ & 0.28 & 0.33 & $(-2.54)$ & $(-2.83)$ \\
Observations & 1,568 & 1,568 & 0.16 & 0.20 \\
& & & 1,492 & 1,492 \\
\hline \hline
\end{tabular}


Table 5:

Failed versus Non-Failed Banks

This table compares means of characteristics of banks that failed and banks that did not fail, in a particular year, during the East Asian crisis. Observations here are bank-year pairs, for the years 1997-2002. Size is the dollar value of the bank's assets, given current exchange rates. Profitability is defined as return on assets (ROA). Maturing debt is the dollar amount of debt principal that is due in the current year and was issued before the specified year.

\begin{tabular}{lccccc}
\hline \hline & Size & Profitability & Debt Ratio & Deposit Ratio & Obs. \\
\hline Failed banks & $\$ 12,234 \mathrm{~m}$ & $-8.2 \%$ & $99.7 \%$ & $20.5 \%$ & 111 \\
& & & & $20.2 \%$ & 1,314 \\
Non-failed banks & $\$ 4,688 \mathrm{~m}$ & $-0.5 \%$ & $86.8 \%$ & & \\
Difference & $\$ 7,546 \mathrm{~m}$ & $-7.7 \%$ & $12.9 \%$ & $0.3 \%$ & $(1.28)$ \\
T-test & $(4.12)$ & $(-4.05)$ & $(7.70)$ & & \\
& & & & & \\
\hline \hline
\end{tabular}




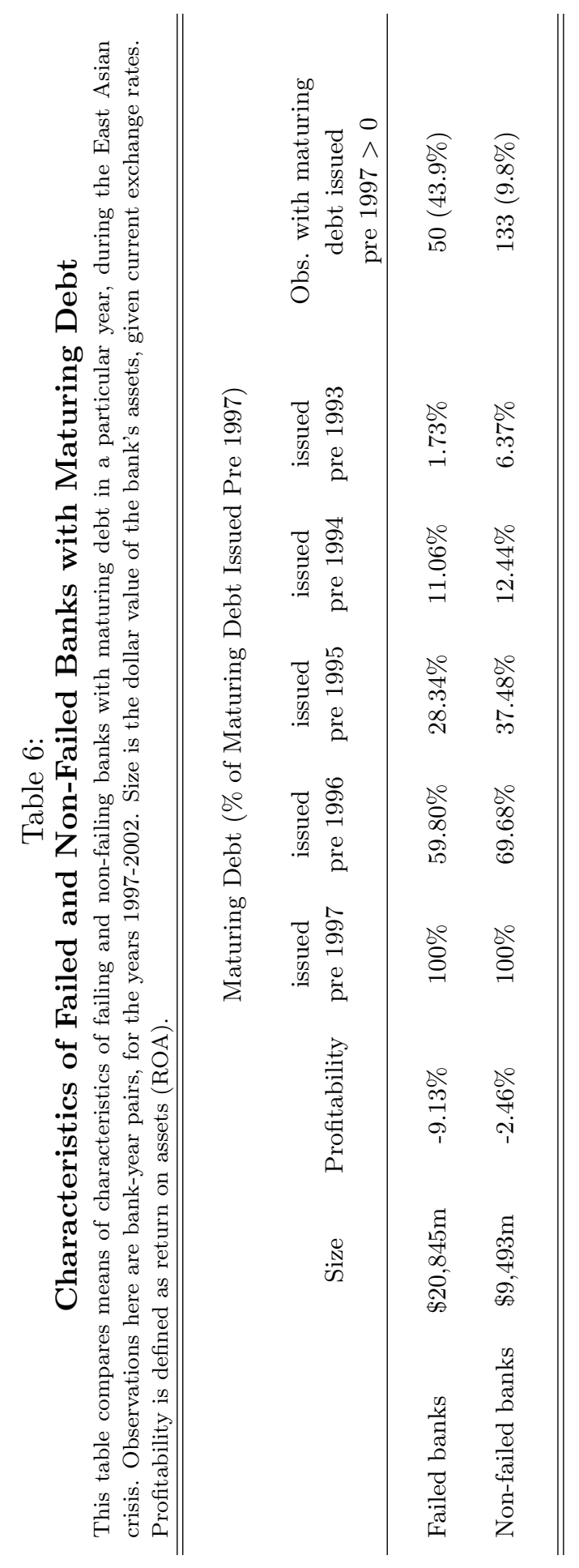


Table 7:

Short-Term Debt and Bank Failure with Bank-Level Financial Controls

The dependent variable in the regressions is a dummy variable that equals 1 for failed banks in the year of failure. Size is the $\log$ of the dollar value of the bank's assets. Profitability is defined as return on assets (ROA). Debt outstanding is the principal amount of debt, issued before particular years, that will become due in future years, as a fraction of overall bank assets. Debt maturing this year is the principal amount of debt, issued before particular years, that is due in the current year, again as a fraction of overall bank assets. All regressions include an intercept (not reported). Panel B specifications include country and year fixed- effects. Regressions are estimated using probit (marginal effects are reported). $t$-statistics, calculated using standard- errors that are clustered by country, are reported in parentheses. Magnitudes are calculated relative to the observed probability of bank failure in our sample, given at $6.31 \%$.

\begin{tabular}{|c|c|c|c|c|c|c|}
\hline \multicolumn{7}{|c|}{ Panel A: Bank Failures } \\
\hline Variable $=$ & $\operatorname{Pr}($ Failure $)$ & $\operatorname{Pr}$ (Failure) & $\operatorname{Pr}$ (Failure) & $\operatorname{Pr}$ (Failure) & $\operatorname{Pr}($ Failure $)$ & $\operatorname{Pr}$ (Failure) \\
\hline Size & $\begin{array}{c}0.016 \mathrm{a} \\
(3.95)\end{array}$ & $\begin{array}{c}0.016 \mathrm{a} \\
(3.88)\end{array}$ & $\begin{array}{c}0.017 \mathrm{a} \\
(3.94)\end{array}$ & $\begin{array}{c}0.015 \mathrm{a} \\
(3.75)\end{array}$ & $\begin{array}{c}0.016 \mathrm{a} \\
(3.89)\end{array}$ & $\begin{array}{c}0.016 \mathrm{a} \\
(3.74)\end{array}$ \\
\hline Profitability & $\begin{array}{c}-0.003 \mathrm{a} \\
(-5.26)\end{array}$ & $\begin{array}{c}-0.003 \mathrm{a} \\
(-5.73)\end{array}$ & $\begin{array}{c}-0.003 \mathrm{a} \\
(-5.35)\end{array}$ & $\begin{array}{c}-0.003 \mathrm{a} \\
(-5.69)\end{array}$ & $\begin{array}{c}-0.003 \mathrm{a} \\
(-5.74)\end{array}$ & $\begin{array}{c}-0.003 \mathrm{a} \\
(-5.11)\end{array}$ \\
\hline Debt outstanding & & $\begin{array}{l}-0.003 \\
(-0.14)\end{array}$ & $\begin{array}{l}0.060 \mathrm{~b} \\
(2.12)\end{array}$ & $\begin{array}{c}0.504 \mathrm{a} \\
(3.66)\end{array}$ & $\begin{array}{c}0.945 \mathrm{a} \\
(4.76)\end{array}$ & $\begin{array}{l}3.555 \\
(1.50)\end{array}$ \\
\hline $\begin{array}{l}\text { Debt maturing } \\
\text { this year }\end{array}$ & & $\begin{array}{c}0.142 \mathrm{a} \\
(2.90)\end{array}$ & $\begin{array}{l}-0.019 \\
(-0.47)\end{array}$ & $\begin{array}{c}-0.550 \mathrm{a} \\
(-2.83)\end{array}$ & $\begin{array}{c}-1.763 \mathrm{~b} \\
(-2.50)\end{array}$ & $\begin{array}{r}-10.185 \\
(-0.94)\end{array}$ \\
\hline issued & & pre 1997 & pre 1996 & pre 1995 & pre 1994 & pre 1993 \\
\hline Pseudo $R^{2}$ & 0.10 & 0.10 & 0.10 & 0.10 & 0.10 & 0.10 \\
\hline Observations & 1,776 & 1,776 & 1,776 & 1,776 & 1,776 & 1,776 \\
\hline \multirow[t]{2}{*}{ Magnitude of effect } & & \multicolumn{5}{|c|}{ Maturing debt issued: } \\
\hline & & pre 1997 & pre 1996 & pre 1995 & pre 1994 & pre 1993 \\
\hline one $\sigma$ change & & $13.2 \%$ & & $-10.3 \%$ & $-18.2 \%$ & - \\
\hline \multicolumn{7}{|c|}{ Panel B: Bank Failures Fixed-Effects Regressions } \\
\hline $\begin{array}{l}\text { Dependent } \\
\text { Variable= }\end{array}$ & $\operatorname{Pr}$ (Failure) & $\operatorname{Pr}$ (Failure) & $\operatorname{Pr}$ (Failure) & $\operatorname{Pr}$ (Failure) & $\operatorname{Pr}$ (Failure) & $\operatorname{Pr}($ Failure $)$ \\
\hline Size & $\begin{array}{c}0.005 \mathrm{c} \\
(1.72)\end{array}$ & $\begin{array}{c}0.005 \mathrm{c} \\
(1.74)\end{array}$ & $\begin{array}{c}0.005 \mathrm{c} \\
(1.71)\end{array}$ & $\begin{array}{c}0.005 \mathrm{c} \\
(1.64)\end{array}$ & $\begin{array}{l}0.005 \mathrm{c} \\
(1.87)\end{array}$ & $\begin{array}{c}0.005 \mathrm{c} \\
(1.72)\end{array}$ \\
\hline Profitability & $\begin{array}{c}-0.002 \mathrm{a} \\
(-9.86)\end{array}$ & $\begin{array}{c}-0.002 \mathrm{a} \\
(-9.81)\end{array}$ & $\begin{array}{c}-0.002 \mathrm{a} \\
(-9.78)\end{array}$ & $\begin{array}{c}-0.002 \mathrm{a} \\
(-9.51)\end{array}$ & $\begin{array}{l}-0.002 \mathrm{a} \\
(-10.71)\end{array}$ & $\begin{array}{c}-0.002 \mathrm{a} \\
(-9.89)\end{array}$ \\
\hline Debt outstanding & & $\begin{array}{l}-0.008 \\
(-0.62)\end{array}$ & $\begin{array}{l}0.040 \\
(1.27)\end{array}$ & $\begin{array}{c}0.350 \mathrm{a} \\
(5.64)\end{array}$ & $\begin{array}{l}0.621 \\
(5.46)\end{array}$ & $\begin{array}{l}1.930 \\
(1.03)\end{array}$ \\
\hline $\begin{array}{l}\text { Debt maturing } \\
\text { this year }\end{array}$ & & $\begin{array}{l}0.059 \\
(1.62)\end{array}$ & $\begin{array}{l}-0.071 \\
(-0.86)\end{array}$ & $\begin{array}{l}-0.565 \mathrm{a} \\
(-18.73)\end{array}$ & $\begin{array}{c}-1.406 \mathrm{a} \\
(-3.77)\end{array}$ & $\begin{array}{l}-7.389 \\
(-0.95)\end{array}$ \\
\hline issued & & pre 1997 & pre 1996 & pre 1995 & pre 1994 & pre 1993 \\
\hline Country and Year FE & Yes & Yes & Yes & Yes & Yes & Yes \\
\hline Pseudo $R^{2}$ & 0.19 & 0.19 & 0.19 & 0.19 & 0.19 & 0.19 \\
\hline Observations & 1,776 & 1,776 & 1,776 & 1,776 & 1,776 & 1,776 \\
\hline Magnitude of effect & & & & Maturing de & t issued: & \\
\hline & & pre 1997 & pre 1996 & pre 1995 & pre 1994 & pre 1993 \\
\hline one $\sigma$ change & & - & - & $-10.58 \%$ & $-14.52 \%$ & - \\
\hline
\end{tabular}




\section{Table 8:}

\section{Hazard Regressions: Short-Term Debt and Bank Failure}

These regressions are estimated using the Cox semi-parametric maximum likelihood proportional hazard model. The dependent variable is the annual probability of failure - that is, the hazard function of time until failure, starting from 1996. Size is the log of the dollar value of the bank's assets. Profitability is defined as return on assets (ROA). Debt outstanding is the principal amount of debt, issued before particular years, that will become due in future years, as a fraction of overall bank assets. Debt maturing this year is the principal amount of debt, issued before particular years, that is due in the current year, again as a fraction of overall bank assets. All regressions include an intercept (not reported). Panel B specifications include country and year fixed- effects. $t$-statistics, calculated using standard- errors that are clustered by country, are reported in parentheses.

\begin{tabular}{|c|c|c|c|c|c|c|}
\hline \multicolumn{7}{|c|}{ Panel A: Bank Failures } \\
\hline Variable $=$ & $\lambda(t)$ & $\lambda(t)$ & $\lambda(t)$ & $\lambda(t)$ & $\lambda(t)$ & $\lambda(t)$ \\
\hline Size & $\begin{array}{c}0.340 \mathrm{a} \\
(4.12)\end{array}$ & $\begin{array}{c}0.335 \mathrm{a} \\
(4.07)\end{array}$ & $\begin{array}{c}0.331 \mathrm{a} \\
(4.00)\end{array}$ & $\begin{array}{c}0.325 \mathrm{a} \\
(3.71)\end{array}$ & $\begin{array}{c}0.340 \mathrm{a} \\
(4.65)\end{array}$ & $\begin{array}{c}0.338 \mathrm{a} \\
(4.07)\end{array}$ \\
\hline Profitability & $\begin{array}{c}-0.023 \mathrm{a} \\
(-9.23)\end{array}$ & $\begin{array}{c}-0.023 \mathrm{a} \\
(-9.51)\end{array}$ & $\begin{array}{c}-0.023 \mathrm{a} \\
(-9.30)\end{array}$ & $\begin{array}{c}-0.023 \mathrm{a} \\
(-9.77)\end{array}$ & $\begin{array}{c}-0.023 \mathrm{a} \\
(-9.47)\end{array}$ & $\begin{array}{c}-0.023 \mathrm{a} \\
(-8.52)\end{array}$ \\
\hline Debt outstanding & & $\begin{array}{l}-0.005 \\
(-0.01)\end{array}$ & $\begin{array}{l}1.224 \\
(1.43)\end{array}$ & $\begin{array}{c}9.155 \mathrm{a} \\
(2.56)\end{array}$ & $\begin{array}{c}15.78 \mathrm{a} \\
(3.73)\end{array}$ & $\begin{array}{l}23.436 \\
(1.34)\end{array}$ \\
\hline $\begin{array}{l}\text { Debt maturing } \\
\text { this year }\end{array}$ & & $\begin{array}{l}2.015 \mathrm{c} \\
(1.90)\end{array}$ & $\begin{array}{l}-0.975 \\
(-0.80)\end{array}$ & $\begin{array}{c}-15.071 \mathrm{a} \\
(-4.18)\end{array}$ & $\begin{array}{c}-33.663 \mathrm{a} \\
(-9.52)\end{array}$ & $\begin{array}{l}-98.819 \\
(-1.11)\end{array}$ \\
\hline issued & & pre 1997 & pre 1996 & pre 1995 & pre 1994 & pre 1993 \\
\hline Observations & 1,462 & 1,462 & 1,462 & 1,462 & 1,462 & 1,462 \\
\hline Magnitude of effect & & \multicolumn{5}{|c|}{ Maturing debt issued: } \\
\hline one $\sigma$ change & & $12.31 \%$ & - & $-17.09 \%$ & $-20.58 \%$ & - \\
\hline
\end{tabular}

Panel B: Bank Failures Fixed-Effects Regressions

\begin{tabular}{|c|c|c|c|c|c|c|}
\hline \multicolumn{7}{|l|}{ Dependent } \\
\hline Variable $=$ & $\lambda(t)$ & $\lambda(t)$ & $\lambda(t)$ & $\lambda(t)$ & $\lambda(t)$ & $\lambda(t)$ \\
\hline Size & $\begin{array}{c}0.152 \mathrm{~b} \\
(2.01)\end{array}$ & $\begin{array}{c}0.152 \mathrm{~b} \\
(2.03)\end{array}$ & $\begin{array}{c}0.146 \mathrm{c} \\
(1.94)\end{array}$ & $\begin{array}{c}0.143 \mathrm{c} \\
(1.92)\end{array}$ & $\begin{array}{c}0.156 \mathrm{~b} \\
(2.06)\end{array}$ & $\begin{array}{c}0.152 \mathrm{~b} \\
(2.03)\end{array}$ \\
\hline Profitability & $\begin{array}{l}-0.043 \mathrm{a} \\
(-13.56)\end{array}$ & $\begin{array}{l}-0.043 \mathrm{a} \\
(-13.77)\end{array}$ & $\begin{array}{c}-0.043 \mathrm{a} \\
(-13.77)\end{array}$ & $\begin{array}{l}-0.043 \mathrm{a} \\
(-15.51)\end{array}$ & $\begin{array}{c}-0.042 \mathrm{a} \\
(-17.77)\end{array}$ & $\begin{array}{l}-0.043 \mathrm{a} \\
(-14.90)\end{array}$ \\
\hline Overall debt & & $\begin{array}{l}0.279 \\
(1.21)\end{array}$ & $\begin{array}{c}1.247 \mathrm{a} \\
(2.64)\end{array}$ & $\begin{array}{c}5.265 \mathrm{a} \\
(2.99)\end{array}$ & $\begin{array}{c}9.892 \mathrm{a} \\
(5.72)\end{array}$ & $\begin{array}{c}23.765 \mathrm{a} \\
(3.07)\end{array}$ \\
\hline $\begin{array}{l}\text { Debt maturing } \\
\text { this year }\end{array}$ & & $\begin{array}{l}-0.016 \\
(-0.04)\end{array}$ & $\begin{array}{l}-2.233 \\
(-1.31)\end{array}$ & $\begin{array}{c}-6.900 \mathrm{a} \\
(-3.04)\end{array}$ & $\begin{array}{c}-18.118 \mathrm{a} \\
(-3.38)\end{array}$ & $\begin{array}{c}-96.52 b \\
(-1.99)\end{array}$ \\
\hline issued & & pre 1997 & pre 1996 & pre 1995 & pre 1994 & pre 1993 \\
\hline Country and Year FE & Yes & Yes & Yes & Yes & Yes & Yes \\
\hline Observations & 1,462 & 1,462 & 1,462 & 1,462 & 1,462 & 1,462 \\
\hline \multirow[t]{2}{*}{ Magnitude of effect } & & \multicolumn{5}{|c|}{ Maturing debt issued: } \\
\hline & & pre 1997 & pre 1996 & pre 1995 & pre 1994 & pre 1993 \\
\hline one $\sigma$ change & & - & - & $-8.22 \%$ & $-11.66 \%$ & $-20.38 \%$ \\
\hline
\end{tabular}


Table 9:

\section{Robustness I: Probit with Additional Controls}

The dependent variable in the regressions is a dummy variable that equals 1 for failed banks in the year of failure. Size is the $\log$ of the dollar value of the bank's assets. Profitability is defined as return on assets (ROA). Debt-asset ratio is overall bank debt divided by overall assets. Deposit-asset ratio is overall demand deposits at the bank divided by overall bank assets. Debt outstanding is the principal amount of debt, issued before particular years, that will become due in future years, as a fraction of overall bank assets. Debt maturing this year is the principal amount of debt, issued before particular years, that is due in the current year, again as a fraction of overall bank assets. All regressions include an intercept (not reported). Panel B specifications include country and year fixed- effects. Regressions are estimated using probit (marginal effects are reported). $t$-statistics, calculated using standard- errors that are clustered by country, are reported in parentheses. Magnitudes are calculated relative to the observed probability of bank failure in our sample, given at $6.41 \%$.

\begin{tabular}{|c|c|c|c|c|c|c|}
\hline \multicolumn{7}{|c|}{ Panel A: Bank Failures } \\
\hline Variable $=$ & $\operatorname{Pr}($ Failure $)$ & $\operatorname{Pr}($ Failure $)$ & $\operatorname{Pr}($ Failure $)$ & $\operatorname{Pr}($ Failure $)$ & $\operatorname{Pr}($ Failure $)$ & $\operatorname{Pr}($ Failure $)$ \\
\hline Size & $\begin{array}{c}0.015 \mathrm{a} \\
(2.58)\end{array}$ & $\begin{array}{c}0.014 \mathrm{~b} \\
(2.54)\end{array}$ & $\begin{array}{c}0.015 \mathrm{a} \\
(2.59)\end{array}$ & $\begin{array}{c}0.014 \mathrm{~b} \\
(2.43)\end{array}$ & $\begin{array}{c}0.015 \mathrm{~b} \\
(2.54)\end{array}$ & $\begin{array}{c}0.015 \mathrm{~b} \\
(2.42)\end{array}$ \\
\hline Profitability & $\begin{array}{c}-0.003 \mathrm{~b} \\
(-2.01)\end{array}$ & $\begin{array}{c}-0.002 \mathrm{~b} \\
(-2.03)\end{array}$ & $\begin{array}{c}-0.002 \mathrm{~b} \\
(-2.00)\end{array}$ & $\begin{array}{c}-0.002 \mathrm{~b} \\
(-2.00)\end{array}$ & $\begin{array}{c}-0.002 b \\
(-2.00)\end{array}$ & $\begin{array}{c}-0.002 \mathrm{~b} \\
(-1.97)\end{array}$ \\
\hline Debt-Asset Ratio & $\begin{array}{c}0.059 \\
(0.87)\end{array}$ & $\begin{array}{c}0.069 \\
(1.10)\end{array}$ & $\begin{array}{l}0.063 \\
(0.95)\end{array}$ & $\begin{array}{l}0.067 \\
(1.06)\end{array}$ & $\begin{array}{l}0.071 \\
(1.14)\end{array}$ & $\begin{array}{l}0.059 \\
(0.88)\end{array}$ \\
\hline Deposit-Asset Ratio & $\begin{array}{l}0.005 \\
(0.25)\end{array}$ & $\begin{array}{l}0.010 \\
(0.47)\end{array}$ & $\begin{array}{l}0.008 \\
(0.36)\end{array}$ & $\begin{array}{l}0.010 \\
(0.45)\end{array}$ & $\begin{array}{l}0.009 \\
(0.42)\end{array}$ & $\begin{array}{l}0.005 \\
(0.24)\end{array}$ \\
\hline Debt outstanding & & $\begin{array}{l}-0.003 \\
(-0.15)\end{array}$ & $\begin{array}{c}0.059 \mathrm{~b} \\
(1.96)\end{array}$ & $\begin{array}{c}0.532 \mathrm{a} \\
(3.70)\end{array}$ & $\begin{array}{c}1.002 \mathrm{a} \\
(4.56)\end{array}$ & $\begin{array}{l}3.655 \\
(1.56)\end{array}$ \\
\hline $\begin{array}{l}\text { Debt maturing } \\
\text { this year }\end{array}$ & & $\begin{array}{c}0.159 \mathrm{a} \\
(2.56)\end{array}$ & $\begin{array}{c}-0.00001 \\
(-0.00)\end{array}$ & $\begin{array}{c}-0.541 \mathrm{a} \\
(-2.73)\end{array}$ & $\begin{array}{c}-1.791 b \\
(-2.46)\end{array}$ & $\begin{array}{l}-9.971 \\
(-0.92)\end{array}$ \\
\hline issued & & pre 1997 & pre 1996 & pre 1995 & pre 1994 & pre 1993 \\
\hline Pseudo $R^{2}$ & 0.10 & 0.10 & 0.10 & 0.10 & 0.11 & 0.10 \\
\hline Observations & 1,731 & 1,731 & 1,731 & 1,731 & 1,731 & 1,731 \\
\hline Magnitude of effect & & \multicolumn{5}{|c|}{ Maturing debt issued: } \\
\hline & & pre 1997 & pre 1996 & pre 1995 & pre 1994 & pre 1993 \\
\hline one $\sigma$ change & & $14.7 \%$ & & $-10.1 \%$ & $-18.4 \%$ & - \\
\hline \multicolumn{7}{|c|}{ Panel B: Bank Failures Fixed-Effects Regressions } \\
\hline $\begin{array}{l}\text { Dependent } \\
\text { Variable= }\end{array}$ & $\operatorname{Pr}($ Failure $)$ & $\operatorname{Pr}($ Failure $)$ & $\operatorname{Pr}($ Failure $)$ & $\operatorname{Pr}($ Failure $)$ & $\operatorname{Pr}($ Failure $)$ & $\operatorname{Pr}($ Failure $)$ \\
\hline Size & $\begin{array}{l}0.002 \\
(0.49)\end{array}$ & $\begin{array}{l}0.002 \\
(0.49)\end{array}$ & $\begin{array}{l}0.002 \\
(0.47)\end{array}$ & $\begin{array}{l}0.002 \\
(0.38)\end{array}$ & $\begin{array}{l}0.002 \\
(0.58)\end{array}$ & $\begin{array}{l}0.002 \\
(0.48)\end{array}$ \\
\hline Profitability & $\begin{array}{c}-0.001 \mathrm{a} \\
(-2.75)\end{array}$ & $\begin{array}{c}-0.001 \mathrm{a} \\
(-2.66)\end{array}$ & $\begin{array}{c}-0.001 \mathrm{a} \\
(-2.74)\end{array}$ & $\begin{array}{c}-0.001 \mathrm{a} \\
(-2.64)\end{array}$ & $\begin{array}{c}-0.001 \mathrm{a} \\
(-2.71)\end{array}$ & $\begin{array}{c}-0.001 \mathrm{a} \\
(-2.65)\end{array}$ \\
\hline Debt-Asset Ratio & $\begin{array}{c}0.069 \mathrm{~b} \\
(2.03)\end{array}$ & $\begin{array}{c}0.072 \mathrm{~b} \\
(2.07)\end{array}$ & $\begin{array}{c}0.069 \mathrm{~b} \\
(2.08)\end{array}$ & $\begin{array}{c}0.072 \mathrm{~b} \\
(2.12)\end{array}$ & $\begin{array}{c}0.073 \mathrm{~b} \\
(2.18)\end{array}$ & $\begin{array}{c}0.069 \mathrm{~b} \\
(2.03)\end{array}$ \\
\hline Deposit-Asset Ratio & $\begin{array}{l}0.027 \\
(0.91)\end{array}$ & $\begin{array}{l}0.027 \\
(0.92)\end{array}$ & $\begin{array}{l}0.027 \\
(0.92)\end{array}$ & $\begin{array}{l}0.026 \\
(0.90)\end{array}$ & $\begin{array}{l}0.026 \\
(0.91)\end{array}$ & $\begin{array}{l}0.026 \\
(0.91)\end{array}$ \\
\hline Debt outstanding & & $\begin{array}{l}-0.006 \\
(-0.46)\end{array}$ & $\begin{array}{l}0.039 \\
(1.26)\end{array}$ & $\begin{array}{c}0.356 \mathrm{a} \\
(6.09)\end{array}$ & $\begin{array}{c}0.621 \mathrm{a} \\
(5.01)\end{array}$ & $\begin{array}{l}2.018 \\
(1.10)\end{array}$ \\
\hline $\begin{array}{l}\text { Debt maturing } \\
\text { this year }\end{array}$ & & $\begin{array}{l}0.062 \\
(1.60)\end{array}$ & $\begin{array}{l}-0.058 \\
(-0.75)\end{array}$ & $\begin{array}{l}-0.534 \mathrm{a} \\
(-12.26)\end{array}$ & $\begin{array}{c}-1.330 \mathrm{a} \\
(-3.93)\end{array}$ & $\begin{array}{l}-7.085 \\
(-0.93)\end{array}$ \\
\hline issued & & pre 1997 & pre 1996 & pre 1995 & pre 1994 & pre 1993 \\
\hline Country and Year FE & Yes & Yes & Yes & Yes & Yes & Yes \\
\hline Pseudo $R^{2}$ & 0.20 & 0.20 & 0.20 & 0.20 & 0.20 & 0.20 \\
\hline Observations & 1,731 & 1,731 & 1,731 & 1,731 & 1,731 & 1,731 \\
\hline Magnitude of effect & & & & Maturing $d$ & t issued: & \\
\hline & & pre 1997 & pre 1996 & pre 1995 & pre 1994 & pre 1993 \\
\hline one $\sigma$ change & & - & - & $-9.96 \%$ & $-13.68 \%$ & - \\
\hline
\end{tabular}


Table 10:

\section{Robustness II: Hazard Regressions with Additional Controls}

These regressions are estimated using the Cox semi-parametric maximum likelihood proportional hazard model. The dependent variable is the annual probability of failure - that is, the hazard function of time until failure, starting from 1996 . Size is the $\log$ of the dollar value of the bank's assets. Profitability is defined as return on assets (ROA). Debt-asset ratio is overall bank debt divided by overall assets. Deposit-asset ratio is overall demand deposits at the bank divided by overall bank assets. Debt outstanding is the principal amount of debt, issued before particular years, that will become due in future years, as a fraction of overall bank assets. Debt maturing this year is the principal amount of debt, issued before particular years, that is due in the current year, again as a fraction of overall bank assets. All regressions include an intercept (not reported). Panel B specifications include country and year fixed- effects. $t$-statistics, calculated using standard- errors that are clustered by country, are reported in parentheses.

\begin{tabular}{|c|c|c|c|c|c|c|}
\hline \multicolumn{7}{|c|}{ Panel A: Bank Failures } \\
\hline $\begin{array}{l}\text { Dependent } \\
\text { Variable }=\end{array}$ & $\lambda(t)$ & $\lambda(t)$ & $\lambda(t)$ & $\lambda(t)$ & $\lambda(t)$ & $\lambda(t)$ \\
\hline Size & $\begin{array}{c}0.315 \mathrm{a} \\
(3.13)\end{array}$ & $\begin{array}{c}0.309 \mathrm{a} \\
(3.06)\end{array}$ & $\begin{array}{c}0.306 \mathrm{a} \\
(3.06)\end{array}$ & $\begin{array}{c}0.298 \mathrm{a} \\
(2.80)\end{array}$ & $\begin{array}{c}0.310 \mathrm{a} \\
(3.28)\end{array}$ & $\begin{array}{c}0.312 \mathrm{a} \\
(3.07)\end{array}$ \\
\hline Profitability & $\begin{array}{l}-0.008 \\
(-0.75)\end{array}$ & $\begin{array}{l}-0.007 \\
(-0.68)\end{array}$ & $\begin{array}{l}-0.008 \\
(-0.73)\end{array}$ & $\begin{array}{l}-0.007 \\
(-0.67)\end{array}$ & $\begin{array}{l}-0.005 \\
(-0.58)\end{array}$ & $\begin{array}{l}-0.008 \\
(-0.65)\end{array}$ \\
\hline Debt-Asset Ratio & $\begin{array}{l}1.184 \\
(1.19)\end{array}$ & $\begin{array}{l}1.347 \\
(1.46)\end{array}$ & $\begin{array}{l}1.227 \\
(1.27)\end{array}$ & $\begin{array}{l}1.280 \\
(1.36)\end{array}$ & $\begin{array}{l}1.471 \mathrm{c} \\
(1.84)\end{array}$ & $\begin{array}{l}1.206 \\
(1.18)\end{array}$ \\
\hline Deposit-Asset Ratio & $\begin{array}{l}-0.155 \\
(-0.44)\end{array}$ & $\begin{array}{l}-0.080 \\
(-0.21)\end{array}$ & $\begin{array}{l}-0.119 \\
(-0.32)\end{array}$ & $\begin{array}{l}-0.091 \\
(-0.24)\end{array}$ & $\begin{array}{l}-0.098 \\
(-0.26)\end{array}$ & $\begin{array}{l}-0.162 \\
(-0.44)\end{array}$ \\
\hline Debt outstanding & & $\begin{array}{l}-0.032 \\
(-0.07)\end{array}$ & $\begin{array}{l}1.189 \\
(1.38)\end{array}$ & $\begin{array}{c}9.274 \mathrm{a} \\
(2.32)\end{array}$ & $\begin{array}{c}17.542 \mathrm{a} \\
(3.12)\end{array}$ & $\begin{array}{l}24.975 \\
(1.37)\end{array}$ \\
\hline $\begin{array}{l}\text { Debt maturing } \\
\text { this year }\end{array}$ & & $\begin{array}{c}2.297 \mathrm{~b} \\
(1.99)\end{array}$ & $\begin{array}{l}-0.742 \\
(-0.63)\end{array}$ & $\begin{array}{c}-14.681 \mathrm{a} \\
(-3.91)\end{array}$ & $\begin{array}{c}-37.044 \mathrm{a} \\
(-6.23)\end{array}$ & $\begin{array}{c}-102.015 \\
(-1.15)\end{array}$ \\
\hline issued & & pre 1997 & pre 1996 & pre 1995 & pre 1994 & pre 1993 \\
\hline Observations & 1,421 & 1,421 & 1,421 & 1,421 & 1,421 & 1,421 \\
\hline \multirow[t]{2}{*}{ Magnitude of effect } & & \multicolumn{5}{|c|}{ Maturing debt issued: } \\
\hline & & pre 1997 & pre 1996 & pre 1995 & pre 1994 & pre 1993 \\
\hline one $\sigma$ change & & $14.37 \%$ & - & $-16.90 \%$ & $-22.67 \%$ & - \\
\hline \multicolumn{7}{|c|}{ Panel B: Bank Failures Fixed-Effects Regressions } \\
\hline \multicolumn{7}{|l|}{ Dependent } \\
\hline Variable $=$ & $\lambda(t)$ & $\lambda(t)$ & $\lambda(t)$ & $\lambda(t)$ & $\lambda(t)$ & $\lambda(t)$ \\
\hline Size & $\begin{array}{l}0.128 \\
(1.12)\end{array}$ & $\begin{array}{l}0.127 \\
(1.12)\end{array}$ & $\begin{array}{l}0.122 \\
(1.06)\end{array}$ & $\begin{array}{l}0.116 \\
(1.01)\end{array}$ & $\begin{array}{l}0.129 \\
(1.12)\end{array}$ & $\begin{array}{l}0.127 \\
(1.10)\end{array}$ \\
\hline Profitability & $\begin{array}{c}-0.035 a \\
(-5.00)\end{array}$ & $\begin{array}{c}-0.035 \mathrm{a} \\
(-4.96)\end{array}$ & $\begin{array}{c}-0.035 \mathrm{a} \\
(-5.02)\end{array}$ & $\begin{array}{c}-0.034 \mathrm{a} \\
(-4.80)\end{array}$ & $\begin{array}{c}-0.032 \mathrm{a} \\
(-4.62)\end{array}$ & $\begin{array}{c}-0.034 \mathrm{a} \\
(-4.98)\end{array}$ \\
\hline Debt-Asset Ratio & $\begin{array}{l}0.533 \\
(0.77)\end{array}$ & $\begin{array}{l}0.554 \\
(0.80)\end{array}$ & $\begin{array}{l}0.528 \\
(0.77)\end{array}$ & $\begin{array}{l}0.587 \\
(0.83)\end{array}$ & $\begin{array}{l}0.660 \\
(0.92)\end{array}$ & $\begin{array}{l}0.567 \\
(0.82)\end{array}$ \\
\hline Deposit-Asset Ratio & $\begin{array}{l}1.138 \\
(1.37)\end{array}$ & $\begin{array}{l}1.138 \\
(1.38)\end{array}$ & $\begin{array}{l}1.142 \\
(1.38)\end{array}$ & $\begin{array}{l}1.137 \\
(1.37)\end{array}$ & $\begin{array}{l}1.151 \\
(1.38)\end{array}$ & $\begin{array}{l}1.129 \\
(1.37)\end{array}$ \\
\hline Debt outstanding & & $\begin{array}{l}0.302 \\
(1.21)\end{array}$ & $\begin{array}{l}1.284 \mathrm{a} \\
(2.76)\end{array}$ & $\begin{array}{c}5.412 \mathrm{a} \\
(3.04)\end{array}$ & $\begin{array}{c}10.381 \mathrm{a} \\
(6.04)\end{array}$ & $\begin{array}{c}25.133 \mathrm{a} \\
(3.49)\end{array}$ \\
\hline $\begin{array}{l}\text { Debt maturing } \\
\text { this year }\end{array}$ & & $\begin{array}{l}-0.024 \\
(-0.06)\end{array}$ & $\begin{array}{l}-2.253 \\
(-1.50)\end{array}$ & $\begin{array}{l}-6.911 \mathrm{a} \\
(-3.02)\end{array}$ & $\begin{array}{c}-19.192 \mathrm{a} \\
(-3.42)\end{array}$ & $\begin{array}{c}-98.869 \mathrm{~b} \\
(-2.12)\end{array}$ \\
\hline issued & & pre 1997 & pre 1996 & pre 1995 & pre 1994 & pre 1993 \\
\hline Country and Year FE & Yes & Yes & Yes & Yes & Yes & Yes \\
\hline Observations & 1,421 & 1,421 & 1,421 & 1,421 & 1,421 & 1,421 \\
\hline Magnitude of effect & & & & Mat & ing debt is & \\
\hline & & pre 1997 & pre 1996 & pre 1995 & pre 1994 & pre 1993 \\
\hline one $\sigma$ change & & - & - & $-8.35 \%$ & $-12.47 \%$ & $-20.82 \%$ \\
\hline
\end{tabular}


Table 11:

\section{Complementary Log-Log Regressions: Short-Term Debt and Bank Failure}

These regressions are estimated using the complementary log-log model. The dependent variable is a dummy variable that equals 1 for failed banks in the year of failure. Size is the log of the dollar value of the bank's assets. Profitability is defined as return on assets (ROA). Debt-asset ratio is overall bank debt divided by overall assets. Deposit-asset ratio is overall demand deposits at the bank divided by overall bank assets. Debt outstanding is the principal amount of debt, issued before particular years, that will become due in future years, as a fraction of overall bank assets. Debt maturing this year is the principal amount of debt, issued before particular years, that is due in the current year, again as a fraction of overall bank assets. All regressions include an intercept (not reported). Panel B specifications include country and year fixed- effects. $t$-statistics, calculated using standard- errors that are clustered by country, are reported in parentheses.

\begin{tabular}{|c|c|c|c|c|c|c|}
\hline \multicolumn{7}{|c|}{ Panel A: Bank Failures } \\
\hline Variable $=$ & $\operatorname{Pr}($ Failure $)$ & $\operatorname{Pr}($ Failure $)$ & $\operatorname{Pr}($ Failure $)$ & $\operatorname{Pr}($ Failure $)$ & $\operatorname{Pr}($ Failure $)$ & $\operatorname{Pr}($ Failure $)$ \\
\hline Size & $\begin{array}{c}0.283 \mathrm{a} \\
(2.91)\end{array}$ & $\begin{array}{c}0.281 \mathrm{a} \\
(2.93)\end{array}$ & $\begin{array}{c}0.281 \mathrm{a} \\
(2.96)\end{array}$ & $\begin{array}{c}0.268 \mathrm{a} \\
(2.76)\end{array}$ & $\begin{array}{c}0.293 \mathrm{a} \\
(2.96)\end{array}$ & $\begin{array}{c}0.279 \mathrm{a} \\
(2.78)\end{array}$ \\
\hline Profitability & $\begin{array}{c}-0.033 \mathrm{~b} \\
(-1.99)\end{array}$ & $\begin{array}{c}-0.031 \mathrm{~b} \\
(-2.06)\end{array}$ & $\begin{array}{c}-0.032 \mathrm{~b} \\
(-1.99)\end{array}$ & $\begin{array}{c}-0.032 \mathrm{c} \\
(-1.93)\end{array}$ & $\begin{array}{c}-0.032 \mathrm{~b} \\
(-2.06)\end{array}$ & $\begin{array}{c}-0.032 \mathrm{c} \\
(-1.90)\end{array}$ \\
\hline Debt-Asset Ratio & $\begin{array}{l}0.874 \\
(0.73)\end{array}$ & $\begin{array}{l}1.025 \\
(0.96)\end{array}$ & $\begin{array}{l}0.932 \\
(0.82)\end{array}$ & $\begin{array}{l}0.944 \\
(0.82)\end{array}$ & $\begin{array}{r}0.993 \\
(0.93)\end{array}$ & $\begin{array}{l}0.885 \\
(0.74)\end{array}$ \\
\hline Deposit-Asset Ratio & $\begin{array}{l}0.004 \\
(0.01)\end{array}$ & $\begin{array}{l}0.092 \\
(0.23)\end{array}$ & $\begin{array}{l}0.046 \\
(0.12)\end{array}$ & $\begin{array}{l}0.080 \\
(0.20)\end{array}$ & $\begin{array}{l}0.080 \\
(0.21)\end{array}$ & $\begin{array}{c}-0.0003 \\
(0.01)\end{array}$ \\
\hline Debt outstanding & & $\begin{array}{l}0.039 \\
(0.16)\end{array}$ & $\begin{array}{c}0.883 \mathrm{a} \\
(2.37)\end{array}$ & $\begin{array}{c}7.530 \mathrm{a} \\
(3.66)\end{array}$ & $\begin{array}{c}17.981 \mathrm{a} \\
(5.78)\end{array}$ & $\begin{array}{l}72.196 \\
(1.42)\end{array}$ \\
\hline $\begin{array}{l}\text { Debt maturing } \\
\text { this year }\end{array}$ & & $\begin{array}{c}2.348 \mathrm{a} \\
(2.97)\end{array}$ & $\begin{array}{l}0.200 \\
(0.28)\end{array}$ & $\begin{array}{c}-8.099 \mathrm{a} \\
(-2.90)\end{array}$ & $\begin{array}{c}-38.207 \mathrm{a} \\
(-4.26)\end{array}$ & $\begin{array}{c}-230.160 \\
(-0.92)\end{array}$ \\
\hline issued & & pre 1997 & pre 1996 & pre 1995 & pre 1994 & pre 1993 \\
\hline Observations & 1,731 & 1,731 & 1,731 & 1,731 & 1,731 & 1,731 \\
\hline \multirow[t]{2}{*}{ Magnitude of effect } & & \multicolumn{5}{|c|}{ Maturing debt issued: } \\
\hline & & pre 1997 & pre 1996 & pre 1995 & pre 1994 & pre 1993 \\
\hline one $\sigma$ change & & $14.90 \%$ & & $-9.23 \%$ & $-22.28 \%$ & - \\
\hline \multicolumn{7}{|c|}{ Panel B: Bank Failures Fixed-Effects Regressions } \\
\hline $\begin{array}{l}\text { Dependent } \\
\text { Variable= }\end{array}$ & $\operatorname{Pr}($ Failure $)$ & $\operatorname{Pr}($ Failure $)$ & $\operatorname{Pr}($ Failure $)$ & $\operatorname{Pr}($ Failure $)$ & $\operatorname{Pr}($ Failure $)$ & $\operatorname{Pr}($ Failure $)$ \\
\hline Size & $\begin{array}{l}0.097 \\
(0.89)\end{array}$ & $\begin{array}{l}0.097 \\
(0.89)\end{array}$ & $\begin{array}{l}0.093 \\
(0.86)\end{array}$ & $\begin{array}{l}0.086 \\
(0.81)\end{array}$ & $\begin{array}{l}0.112 \\
(1.06)\end{array}$ & $\begin{array}{l}0.093 \\
(0.86)\end{array}$ \\
\hline Profitability & $\begin{array}{c}-0.029 \mathrm{a} \\
(-2.78)\end{array}$ & $\begin{array}{c}-0.028 \mathrm{a} \\
(-2.70)\end{array}$ & $\begin{array}{c}-0.029 \mathrm{a} \\
(-2.78)\end{array}$ & $\begin{array}{c}-0.028 \mathrm{a} \\
(-2.71)\end{array}$ & $\begin{array}{c}-0.028 \mathrm{a} \\
(-2.94)\end{array}$ & $\begin{array}{c}-0.028 \mathrm{a} \\
(-2.67)\end{array}$ \\
\hline Debt-Asset Ratio & $\begin{array}{c}1.410 \mathrm{~b} \\
(1.75)\end{array}$ & $\begin{array}{l}1.467 \\
(1.79)\end{array}$ & $\begin{array}{l}1.419 \mathrm{c} \\
(1.81)\end{array}$ & $\begin{array}{l}1.455 \mathrm{c} \\
(1.82)\end{array}$ & $\begin{array}{c}1.456 \mathrm{c} \\
(1.94)\end{array}$ & $\begin{array}{l}1.440 \mathrm{c} \\
(1.78)\end{array}$ \\
\hline Deposit-Asset Ratio & $\begin{array}{l}0.966 \\
(1.19)\end{array}$ & $\begin{array}{l}0.965 \\
(1.21)\end{array}$ & $\begin{array}{l}0.968 \\
(1.20)\end{array}$ & $\begin{array}{l}0.964 \\
(1.19)\end{array}$ & $\begin{array}{l}0.989 \\
(1.20)\end{array}$ & $\begin{array}{l}0.961 \\
(1.19)\end{array}$ \\
\hline Debt outstanding & & $\begin{array}{c}0.0002 \\
(0.01)\end{array}$ & $\begin{array}{l}0.909 \\
(1.15)\end{array}$ & $\begin{array}{c}8.092 \mathrm{a} \\
(5.57)\end{array}$ & $\begin{array}{c}15.345 \mathrm{a} \\
(5.02)\end{array}$ & $\begin{array}{c}61.102 \\
(1.33)\end{array}$ \\
\hline $\begin{array}{l}\text { Debt maturing } \\
\text { this year }\end{array}$ & & $\begin{array}{l}1.037 \\
(1.67)\end{array}$ & $\begin{array}{l}-1.244 \\
(-0.64)\end{array}$ & $\begin{array}{c}-13.169 \mathrm{a} \\
(-7.27)\end{array}$ & $\begin{array}{c}-34.229 \mathrm{a} \\
(-4.57)\end{array}$ & $\begin{array}{c}-235.698 \\
(-1.13)\end{array}$ \\
\hline issued & & pre 1997 & pre 1996 & pre 1995 & pre 1994 & pre 1993 \\
\hline Country and Year FE & Yes & Yes & Yes & Yes & Yes & Yes \\
\hline Observations & 1,731 & 1,731 & 1,731 & 1,731 & 1,731 & 1,731 \\
\hline Magnitude of effect & & & & Maturing d & t issued: & \\
\hline & & pre 1997 & pre 1996 & pre 1995 & pre 1994 & pre 1993 \\
\hline one $\sigma$ change & & - & - & $-14.57 \%$ & $-20.22 \%$ & - \\
\hline
\end{tabular}




\section{Appendix A: Additional Results}

Table A1

\section{Complementary Log-Log Regressions: Alternative Definition of Bank Failure}

These regressions are estimated using the complementary log-log model. The dependent variable is a dummy variable that equals 1 for failed banks in the year of failure. Banks who have merged with other banks do not count as having failed in these regressions, resulting in 71 observed failures. Size is the log of the dollar value of the bank's assets. Profitability is defined as return on assets (ROA). Debt-asset ratio is overall bank debt divided by overall assets. Deposit-asset ratio is overall demand deposits at the bank divided by overall bank assets. Debt outstanding is the principal amount of debt, issued before particular years, that will become due in future years, as a fraction of overall bank assets. Debt maturing this year is the principal amount of debt, issued before particular years, that is due in the current year, again as a fraction of overall bank assets. All regressions include an intercept (not reported). Panel B specifications include country and year fixed- effects. $t$-statistics, calculated using standard- errors that are clustered by country, are reported in parentheses.

\begin{tabular}{|c|c|c|c|c|c|c|}
\hline \multicolumn{7}{|c|}{ Panel A: Bank Failures } \\
\hline Variable $=$ & $\operatorname{Pr}($ Failure $)$ & $\operatorname{Pr}($ Failure $)$ & $\operatorname{Pr}($ Failure $)$ & $\operatorname{Pr}($ Failure $)$ & $\operatorname{Pr}($ Failure $)$ & $\operatorname{Pr}($ Failure $)$ \\
\hline Size & $\begin{array}{c}0.469 \mathrm{a} \\
(6.16)\end{array}$ & $\begin{array}{c}0.464 \mathrm{a} \\
(5.84)\end{array}$ & $\begin{array}{c}0.464 \mathrm{a} \\
(5.91)\end{array}$ & $\begin{array}{c}0.452 \mathrm{a} \\
(6.34)\end{array}$ & $\begin{array}{c}0.486 \mathrm{a} \\
(6.64)\end{array}$ & $\begin{array}{c}0.466 \mathrm{a} \\
(6.26)\end{array}$ \\
\hline Profitability & $\begin{array}{c}-0.056 \mathrm{~b} \\
(-2.27)\end{array}$ & $\begin{array}{c}-0.053 \mathrm{~b} \\
(-2.27)\end{array}$ & $\begin{array}{c}-0.054 \mathrm{~b} \\
(-2.20)\end{array}$ & $\begin{array}{c}-0.054 \mathrm{~b} \\
(-2.22)\end{array}$ & $\begin{array}{c}-0.055 \mathrm{~b} \\
(-2.29)\end{array}$ & $\begin{array}{c}-0.055 \mathrm{~b} \\
(-2.25)\end{array}$ \\
\hline Debt-Asset Ratio & $\begin{array}{l}-0.674 \\
(-0.35)\end{array}$ & $\begin{array}{l}-0.429 \\
(-0.24)\end{array}$ & $\begin{array}{l}-0.561 \\
(-0.30)\end{array}$ & $\begin{array}{l}-0.574 \\
(-0.31)\end{array}$ & $\begin{array}{l}-0.495 \\
(-0.27)\end{array}$ & $\begin{array}{l}-0.670 \\
(-0.36)\end{array}$ \\
\hline Deposit-Asset Ratio & $\begin{array}{c}-1.709 \mathrm{a} \\
(-3.89)\end{array}$ & $\begin{array}{c}-1.594 \mathrm{a} \\
(-3.57)\end{array}$ & $\begin{array}{c}-1.649 \mathrm{a} \\
(-3.73)\end{array}$ & $\begin{array}{c}-1.629 \mathrm{a} \\
(-3.52)\end{array}$ & $\begin{array}{c}-1.612 \mathrm{a} \\
(-3.67)\end{array}$ & $\begin{array}{c}-1.721 \mathrm{a} \\
(-3.87)\end{array}$ \\
\hline Debt outstanding & & $\begin{array}{l}0.158 \\
(1.03)\end{array}$ & $\begin{array}{c}1.138 \mathrm{a} \\
(4.31)\end{array}$ & $\begin{array}{c}7.270 \mathrm{a} \\
(3.66)\end{array}$ & $\begin{array}{c}18.087 \mathrm{a} \\
(4.59)\end{array}$ & $\begin{array}{l}72.766 \\
(1.33)\end{array}$ \\
\hline $\begin{array}{l}\text { Debt maturing } \\
\text { this year }\end{array}$ & & $\begin{array}{c}2.266 \mathrm{a} \\
(3.40)\end{array}$ & $\begin{array}{l}0.059 \\
(0.06)\end{array}$ & $\begin{array}{c}-7.794 \mathrm{~b} \\
(-1.98)\end{array}$ & $\begin{array}{c}-36.669 \mathrm{a} \\
(-2.94)\end{array}$ & $\begin{array}{c}-245.328 \\
(-0.92)\end{array}$ \\
\hline issued & & pre 1997 & pre 1996 & pre 1995 & pre 1994 & pre 1993 \\
\hline Observations & 1,731 & 1,731 & 1,731 & 1,731 & 1,731 & 1,731 \\
\hline Magnitude of effect & & \multicolumn{5}{|c|}{ Maturing debt issued: } \\
\hline & & pre 1997 & pre 1996 & pre 1995 & pre 1994 & pre 1993 \\
\hline one $\sigma$ change & & $14.35 \%$ & & $-8.90 \%$ & $-21.49 \%$ & - \\
\hline \multicolumn{7}{|c|}{ Panel B: Bank Failures Fixed-Effects Regressions } \\
\hline Dependent & & & & & & \\
\hline Variable $=$ & $\operatorname{Pr}($ Failure $)$ & $\operatorname{Pr}($ Failure $)$ & $\operatorname{Pr}($ Failure $)$ & $\operatorname{Pr}($ Failure $)$ & $\operatorname{Pr}($ Failure $)$ & $\operatorname{Pr}($ Failure $)$ \\
\hline Size & $\begin{array}{c}0.323 \mathrm{a} \\
(5.63)\end{array}$ & $\begin{array}{c}0.325 \mathrm{a} \\
(6.75)\end{array}$ & $\begin{array}{c}0.320 \mathrm{a} \\
(5.76)\end{array}$ & $\begin{array}{c}0.310 \mathrm{a} \\
(5.45)\end{array}$ & $\begin{array}{c}0.336 \mathrm{a} \\
(7.21)\end{array}$ & $\begin{array}{c}0.324 \mathrm{a} \\
(6.21)\end{array}$ \\
\hline Profitability & $\begin{array}{c}-0.049 \mathrm{a} \\
(-3.80)\end{array}$ & $\begin{array}{c}-0.048 \mathrm{a} \\
(-3.78)\end{array}$ & $\begin{array}{c}-0.048 \mathrm{a} \\
(-3.85)\end{array}$ & $\begin{array}{c}-0.048 \mathrm{a} \\
(-3.87)\end{array}$ & $\begin{array}{c}-0.047 \mathrm{a} \\
(-3.76)\end{array}$ & $\begin{array}{c}-0.047 \mathrm{a} \\
(-3.67)\end{array}$ \\
\hline Debt-Asset Ratio & $\begin{array}{l}-0.429 \\
(-0.53)\end{array}$ & $\begin{array}{l}-0.377 \\
(-0.48)\end{array}$ & $\begin{array}{l}-0.384 \\
(-0.49)\end{array}$ & $\begin{array}{l}-0.376 \\
(-0.50)\end{array}$ & $\begin{array}{l}-0.321 \\
(-0.41)\end{array}$ & $\begin{array}{l}-0.420 \\
(-0.51)\end{array}$ \\
\hline Deposit-Asset Ratio & $\begin{array}{l}0.964 \\
(0.76)\end{array}$ & $\begin{array}{l}0.998 \\
(0.82)\end{array}$ & $\begin{array}{l}0.968 \\
(0.78)\end{array}$ & $\begin{array}{l}0.960 \\
(0.76)\end{array}$ & $\begin{array}{l}1.073 \\
(0.91)\end{array}$ & $\begin{array}{l}0.967 \\
(0.76)\end{array}$ \\
\hline Debt outstanding & & $\begin{array}{l}-0.055 \\
(-0.12)\end{array}$ & $\begin{array}{l}0.109 \\
(0.30)\end{array}$ & $\begin{array}{c}5.592 \mathrm{a} \\
(6.25)\end{array}$ & $\begin{array}{c}12.810 \mathrm{a} \\
(6.00)\end{array}$ & $\begin{array}{l}47.283 \\
(1.21)\end{array}$ \\
\hline $\begin{array}{l}\text { Debt maturing } \\
\text { this year }\end{array}$ & & $\begin{array}{l}0.966 \\
(0.92)\end{array}$ & $\begin{array}{l}0.628 \\
(0.47)\end{array}$ & $\begin{array}{l}-9.617 \mathrm{a} \\
(-12.14)\end{array}$ & $\begin{array}{c}-29.555 \mathrm{a} \\
(-5.20)\end{array}$ & $\begin{array}{l}-200.00 \\
(-1.07)\end{array}$ \\
\hline issued & & pre 1997 & pre 1996 & pre 1995 & pre 1994 & pre 1993 \\
\hline Country and Year FE & Yes & Yes & Yes & Yes & Yes & Yes \\
\hline Observations & 1,176 & 1,176 & 1,176 & 1,176 & 1,176 & 1,176 \\
\hline Magnitude of effect & & & & Maturing $d$ & t issued: & \\
\hline & & pre 1997 & pre 1996 & pre 1995 & pre 1994 & pre 1993 \\
\hline one $\sigma$ change & & - & - & $-12.73 \%$ & $-20.93 \%$ & - \\
\hline
\end{tabular}


Table A2

\section{Complementary Log-Log Regressions with Money Market Asset Ratio}

These regressions are estimated using the complementary log-log model. The dependent variable is a dummy variable that equals 1 for failed banks in the year of failure. Size is the log of the dollar value of the bank's assets. Profitability is defined as return on assets (ROA). Debt-asset ratio is overall bank debt divided by overall assets. Deposit-asset ratio is overall demand deposits at the bank divided by overall bank assets. Money market-asset ration is overall short-term assets (e.g., CDs and commercial paper) divided by overall bank assets. Debt outstanding is the principal amount of debt, issued before particular years, that will become due in future years, as a fraction of overall bank assets. Debt maturing this year is the principal amount of debt, issued before particular years, that is due in the current year, again as a fraction of overall bank assets. All regressions include an intercept (not reported). Panel B specifications include country and year fixed- effects. $t$-statistics, calculated using standard- errors that are clustered by country, are reported in parentheses.

\begin{tabular}{|c|c|c|c|c|c|c|}
\hline \multicolumn{7}{|c|}{ Panel A: Bank Failures } \\
\hline Variable $=$ & $\operatorname{Pr}$ (Failure) & $\operatorname{Pr}($ Failure $)$ & $\operatorname{Pr}($ Failure $)$ & $\operatorname{Pr}($ Failure $)$ & $\operatorname{Pr}($ Failure $)$ & $\operatorname{Pr}$ (Failure) \\
\hline Size & $\begin{array}{c}0.254 \mathrm{~b} \\
(2.41)\end{array}$ & $\begin{array}{c}0.254 \mathrm{~b} \\
(2.44)\end{array}$ & $\begin{array}{c}0.255 \mathrm{~b} \\
(2.45)\end{array}$ & $\begin{array}{c}0.244 \mathrm{~b} \\
(2.31)\end{array}$ & $\begin{array}{c}0.269 \mathrm{~b} \\
(2.40)\end{array}$ & $\begin{array}{c}0.251 \mathrm{~b} \\
(2.31)\end{array}$ \\
\hline Profitability & $\begin{array}{c}-0.027 \mathrm{a} \\
(-6.58)\end{array}$ & $\begin{array}{c}-0.026 \mathrm{a} \\
(-5.29)\end{array}$ & $\begin{array}{c}-0.026 \mathrm{a} \\
(-6.32)\end{array}$ & $\begin{array}{c}-0.026 \mathrm{a} \\
(-5.85)\end{array}$ & $\begin{array}{c}-0.026 \mathrm{a} \\
(-5.89)\end{array}$ & $\begin{array}{c}-0.025 \mathrm{a} \\
(-7.18)\end{array}$ \\
\hline Debt-Asset Ratio & $\begin{array}{c}1.460 \mathrm{a} \\
(3.71)\end{array}$ & $\begin{array}{c}1.556 \mathrm{a} \\
(3.93)\end{array}$ & $\begin{array}{c}1.478 \mathrm{a} \\
(3.90)\end{array}$ & $\begin{array}{c}1.510 \mathrm{a} \\
(3.83)\end{array}$ & $\begin{array}{c}1.534 \mathrm{a} \\
(3.94)\end{array}$ & $\begin{array}{c}1.404 \mathrm{a} \\
(3.64)\end{array}$ \\
\hline Deposit-Asset Ratio & $\begin{array}{l}0.056 \\
(0.15)\end{array}$ & $\begin{array}{l}0.124 \\
(0.33)\end{array}$ & $\begin{array}{l}0.079 \\
(0.21)\end{array}$ & $\begin{array}{l}0.112 \\
(0.28)\end{array}$ & $\begin{array}{l}0.125 \\
(0.32)\end{array}$ & $\begin{array}{l}0.054 \\
(0.14)\end{array}$ \\
\hline $\begin{array}{l}\text { Money market - } \\
\text { Asset Ratio }\end{array}$ & $\begin{array}{c}-0.906 \mathrm{~b} \\
(-2.23)\end{array}$ & $\begin{array}{c}-0.827 \mathrm{~b} \\
(-2.03)\end{array}$ & $\begin{array}{c}-0.881 \mathrm{~b} \\
(-2.21)\end{array}$ & $\begin{array}{c}-0.870 \mathrm{~b} \\
(-2.13)\end{array}$ & $\begin{array}{c}-0.820 \mathrm{c} \\
(-1.97)\end{array}$ & $\begin{array}{c}-0.912 \mathrm{~b} \\
(-2.28)\end{array}$ \\
\hline Debt outstanding & & $\begin{array}{l}0.142 \\
(0.04)\end{array}$ & $\begin{array}{c}1.527 \mathrm{a} \\
(3.78)\end{array}$ & $\begin{array}{c}7.618 \mathrm{a} \\
(3.49)\end{array}$ & $\begin{array}{c}18.487 \mathrm{a} \\
(8.44)\end{array}$ & $\begin{array}{c}124.267 \\
(1.69)\end{array}$ \\
\hline $\begin{array}{l}\text { Debt maturing } \\
\text { this year }\end{array}$ & & $\begin{array}{c}2.354 \mathrm{~b} \\
(2.01)\end{array}$ & $\begin{array}{l}-2.363 \mathrm{~b} \\
(-2.45)\end{array}$ & $\begin{array}{c}-10.596 \mathrm{a} \\
(-3.05)\end{array}$ & $\begin{array}{c}-38.839 \mathrm{a} \\
(-5.88)\end{array}$ & $\begin{array}{c}-517.917 \\
(-1.11)\end{array}$ \\
\hline issued & & pre 1997 & pre 1996 & pre 1995 & pre 1994 & pre 1993 \\
\hline Observations & 1,256 & 1,256 & 1,256 & 1,256 & 1,256 & 1,256 \\
\hline Magnitude of effect & & \multicolumn{5}{|c|}{ Maturing debt issued: } \\
\hline & & pre 1997 & pre 1996 & pre 1995 & pre 1994 & pre 1993 \\
\hline one $\sigma$ change & & $13.68 \%$ & $-9.80 \%$ & $-12.84 \%$ & $-22.23 \%$ & - \\
\hline \multicolumn{7}{|c|}{ Panel B: Bank Failures Fixed-Effects Regressions } \\
\hline $\begin{array}{l}\text { Dependent } \\
\text { Variable }=\end{array}$ & $\operatorname{Pr}($ Failure $)$ & $\operatorname{Pr}($ Failure $)$ & $\operatorname{Pr}($ Failure $)$ & $\operatorname{Pr}($ Failure $)$ & $\operatorname{Pr}($ Failure $)$ & $\operatorname{Pr}($ Failure $)$ \\
\hline Size & $\begin{array}{l}0.079 \\
(0.70)\end{array}$ & $\begin{array}{l}0.073 \\
(0.65)\end{array}$ & $\begin{array}{l}0.073 \\
(0.66)\end{array}$ & $\begin{array}{l}0.063 \\
(0.58)\end{array}$ & $\begin{array}{l}0.086 \\
(0.76)\end{array}$ & $\begin{array}{l}0.069 \\
(0.60)\end{array}$ \\
\hline Profitability & $\begin{array}{c}-0.027 \mathrm{c} \\
(-1.95)\end{array}$ & $\begin{array}{l}-0.027 \mathrm{c} \\
(-1.87)\end{array}$ & $\begin{array}{l}-0.026 \mathrm{c} \\
(-1.90)\end{array}$ & $\begin{array}{c}-0.027 \mathrm{c} \\
(-1.89)\end{array}$ & $\begin{array}{c}-0.028 \mathrm{~b} \\
(-2.10)\end{array}$ & $\begin{array}{c}-0.025 \mathrm{c} \\
(-1.83)\end{array}$ \\
\hline Debt-Asset Ratio & $\begin{array}{c}1.543 \mathrm{c} \\
(1.66)\end{array}$ & $\begin{array}{l}1.604 \mathrm{c} \\
(1.69)\end{array}$ & $\begin{array}{l}1.544 \mathrm{c} \\
(1.67)\end{array}$ & $\begin{array}{l}1.582 \mathrm{c} \\
(1.70)\end{array}$ & $\begin{array}{l}1.529 \\
(1.76)\end{array}$ & $\begin{array}{l}1.626 \mathrm{c} \\
(1.75)\end{array}$ \\
\hline Deposit-Asset Ratio & $\begin{array}{l}0.088 \\
(0.08)\end{array}$ & $\begin{array}{l}0.097 \\
(0.09)\end{array}$ & $\begin{array}{l}0.109 \\
(0.10)\end{array}$ & $\begin{array}{l}0.108 \\
(0.10)\end{array}$ & $\begin{array}{l}0.141 \\
(0.13)\end{array}$ & $\begin{array}{l}0.084 \\
(0.08)\end{array}$ \\
\hline $\begin{array}{l}\text { Money market - } \\
\text { Asset Ratio }\end{array}$ & $\begin{array}{l}-1.218 \\
(-1.06)\end{array}$ & $\begin{array}{l}-1.199 \\
(-1.05)\end{array}$ & $\begin{array}{l}-1.190 \\
(-1.03)\end{array}$ & $\begin{array}{l}-1.191 \\
(-1.04)\end{array}$ & $\begin{array}{l}-1.153 \\
(-1.01)\end{array}$ & $\begin{array}{l}-1.221 \\
(-1.06)\end{array}$ \\
\hline Debt outstanding & & $\begin{array}{l}0.091 \\
(0.27)\end{array}$ & $\begin{array}{c}2.203 \mathrm{~b} \\
(2.29)\end{array}$ & $\begin{array}{c}9.785 \mathrm{a} \\
(4.39)\end{array}$ & $\begin{array}{c}21.421 \mathrm{a} \\
(7.77)\end{array}$ & $\begin{array}{c}117.657 \\
(1.59)\end{array}$ \\
\hline $\begin{array}{l}\text { Debt maturing } \\
\text { this year }\end{array}$ & & $\begin{array}{c}1.27 \\
(1.00)\end{array}$ & $\begin{array}{c}-5.210 \mathrm{c} \\
(-1.78)\end{array}$ & $\begin{array}{c}-17.727 \mathrm{a} \\
(-6.78)\end{array}$ & $\begin{array}{c}-44.942 \mathrm{a} \\
(-8.89)\end{array}$ & $\begin{array}{c}-531.229 \\
(-1.23)\end{array}$ \\
\hline issued & & pre 1997 & pre 1996 & pre 1995 & pre 1994 & pre 1993 \\
\hline Country and Year FE & Yes & Yes & Yes & Yes & Yes & Yes \\
\hline Observations & 1,256 & 1,256 & 1,256 & 1,256 & 1,256 & 1,256 \\
\hline Magnitude of effect & & pre 1997 & pre 1996 & $\begin{array}{c}\text { Maturing d } \\
\text { pre } 1995\end{array}$ & $\begin{array}{l}\text { issued: } \\
\quad \text { pre } 1994\end{array}$ & pre 1993 \\
\hline one $\sigma$ change & & - & $-20.35 \%$ & $-20.54 \%$ & $-25.24 \%$ & - \\
\hline
\end{tabular}


Table A3

\section{Complementary Log-Log Regressions: Domestic Debt Included}

These regressions are estimated using the complementary log-log model. The dependent variable is a dummy variable that equals 1 for failed banks in the year of failure. Size is the $\log$ of the dollar value of the bank's assets. Profitability is defined as return on assets (ROA). Debt-asset ratio is overall bank debt divided by overall assets. Deposit-asset ratio is overall demand deposits at the bank divided by overall bank assets. Debt outstanding is the principal amount of debt (both domestic and foreign), issued before particular years, that will become due in future years, as a fraction of overall bank assets. Debt maturing this year is the principal amount of debt (both domestic and foreign), issued before particular years, that is due in the current year, again as a fraction of overall bank assets. All regressions include an intercept (not reported). Panel B specifications include country and year fixed- effects. $t$-statistics, calculated using standard- errors that are clustered by country, are reported in parentheses.

\begin{tabular}{|c|c|c|c|c|c|c|}
\hline \multicolumn{7}{|c|}{ Panel A: Bank Failures } \\
\hline Variable $=$ & $\operatorname{Pr}($ Failure $)$ & $\operatorname{Pr}$ (Failure) & $\operatorname{Pr}($ Failure $)$ & $\operatorname{Pr}($ Failure $)$ & $\operatorname{Pr}($ Failure $)$ & $\operatorname{Pr}($ Failure $)$ \\
\hline Size & $\begin{array}{c}0.283 \mathrm{a} \\
(2.91)\end{array}$ & $\begin{array}{c}0.280 \mathrm{a} \\
(2.92)\end{array}$ & $\begin{array}{c}0.281 \mathrm{a} \\
(2.88)\end{array}$ & $\begin{array}{c}0.283 \mathrm{a} \\
(2.81)\end{array}$ & $\begin{array}{c}0.304 \mathrm{a} \\
(2.99)\end{array}$ & $\begin{array}{c}0.282 \mathrm{a} \\
(2.86)\end{array}$ \\
\hline Profitability & $\begin{array}{c}-0.033 \mathrm{~b} \\
(-1.99)\end{array}$ & $\begin{array}{c}-0.032 \mathrm{~b} \\
(-1.94)\end{array}$ & $\begin{array}{c}-0.032 \mathrm{~b} \\
(-2.00)\end{array}$ & $\begin{array}{c}-0.036 \mathrm{~b} \\
(-2.09)\end{array}$ & $\begin{array}{c}-0.039 \mathrm{~b} \\
(-2.42)\end{array}$ & $\begin{array}{c}-0.033 \mathrm{c} \\
(-1.90)\end{array}$ \\
\hline Debt-Asset Ratio & $\begin{array}{l}0.874 \\
(0.73)\end{array}$ & $\begin{array}{c}0.926 \\
(0.80)\end{array}$ & $\begin{array}{l}0.859 \\
(0.74)\end{array}$ & $\begin{array}{l}0.831 \\
(0.70)\end{array}$ & $\begin{array}{l}0.836 \\
(0.80)\end{array}$ & $\begin{array}{l}0.870 \\
(0.72)\end{array}$ \\
\hline Deposit-Asset Ratio & $\begin{array}{l}0.004 \\
(0.01)\end{array}$ & $\begin{array}{l}0.035 \\
(0.33)\end{array}$ & $\begin{array}{l}0.019 \\
(0.05)\end{array}$ & $\begin{array}{l}0.069 \\
(0.18)\end{array}$ & $\begin{array}{l}0.078 \\
(0.20)\end{array}$ & $\begin{array}{l}0.002 \\
(0.01)\end{array}$ \\
\hline Debt outstanding & & $\begin{array}{l}0.035 \\
(0.13)\end{array}$ & $\begin{array}{l}0.496 \\
(1.28)\end{array}$ & $\begin{array}{c}6.824 \mathrm{a} \\
(6.49)\end{array}$ & $\begin{array}{c}15.447 \mathrm{a} \\
(10.90)\end{array}$ & $\begin{array}{c}36.596 \\
(0.96)\end{array}$ \\
\hline $\begin{array}{l}\text { Debt maturing } \\
\text { this year }\end{array}$ & & $\begin{array}{l}1.101 \mathrm{~b} \\
(2.05)\end{array}$ & $\begin{array}{l}-0.314 \\
(-0.45)\end{array}$ & $\begin{array}{c}-12.210 \mathrm{a} \\
(-3.73)\end{array}$ & $\begin{array}{c}-41.841 \mathrm{a} \\
(-4.83)\end{array}$ & $\begin{array}{c}-115.245 \\
(-0.83)\end{array}$ \\
\hline issued & & pre 1997 & pre 1996 & pre 1995 & pre 1994 & pre 1993 \\
\hline Observations & 1,731 & 1,731 & 1,731 & 1,731 & 1,731 & 1,731 \\
\hline \multirow[t]{2}{*}{ Magnitude of effect } & & \multicolumn{5}{|c|}{ Maturing debt issued: } \\
\hline & & pre 1997 & pre 1996 & pre 1995 & pre 1994 & pre 1993 \\
\hline one $\sigma$ change & & $8.60 \%$ & - & $-15.89 \%$ & $-30.32 \%$ & - \\
\hline \multicolumn{7}{|c|}{ Panel B: Bank Failures Fixed-Effects Regressions } \\
\hline $\begin{array}{l}\text { Dependent } \\
\text { Variable }=\end{array}$ & $\operatorname{Pr}($ Failure $)$ & $\operatorname{Pr}($ Failure $)$ & $\operatorname{Pr}($ Failure $)$ & $\operatorname{Pr}($ Failure $)$ & $\operatorname{Pr}$ (Failure) & $\operatorname{Pr}($ Failure $)$ \\
\hline Size & $\begin{array}{l}0.097 \\
(0.89)\end{array}$ & $\begin{array}{l}0.100 \\
(0.92)\end{array}$ & $\begin{array}{l}0.100 \\
(0.91)\end{array}$ & $\begin{array}{l}0.100 \\
(0.89)\end{array}$ & $\begin{array}{l}0.119 \\
(1.09)\end{array}$ & $\begin{array}{l}0.101 \\
(0.92)\end{array}$ \\
\hline Profitability & $\begin{array}{c}-0.029 \mathrm{a} \\
(-2.78)\end{array}$ & $\begin{array}{c}-0.029 \mathrm{a} \\
(-2.74)\end{array}$ & $\begin{array}{c}-0.029 \mathrm{a} \\
(-3.09)\end{array}$ & $\begin{array}{c}-0.031 \mathrm{a} \\
(-3.04)\end{array}$ & $\begin{array}{c}-0.032 \mathrm{a} \\
(-3.32)\end{array}$ & $\begin{array}{c}-0.029 \mathrm{a} \\
(-2.72)\end{array}$ \\
\hline Debt-Asset Ratio & $\begin{array}{c}1.410 \mathrm{c} \\
(1.75)\end{array}$ & $\begin{array}{l}1.448 \mathrm{c} \\
(1.77)\end{array}$ & $\begin{array}{l}1.402 \mathrm{c} \\
(1.67)\end{array}$ & $\begin{array}{l}1.344 \mathrm{c} \\
(1.92)\end{array}$ & $\begin{array}{l}1.361 \mathrm{c} \\
(1.79)\end{array}$ & $\begin{array}{l}1.377 \mathrm{c} \\
(1.67)\end{array}$ \\
\hline Deposit-Asset Ratio & $\begin{array}{l}0.966 \\
(1.19)\end{array}$ & $\begin{array}{l}0.962 \\
(1.19)\end{array}$ & $\begin{array}{l}0.964 \\
(1.17)\end{array}$ & $\begin{array}{l}0.980 \\
(1.20)\end{array}$ & $\begin{array}{l}1.006 \\
(0.21)\end{array}$ & $\begin{array}{l}0.097 \\
(1.20)\end{array}$ \\
\hline Debt outstanding & & $\begin{array}{l}-0.341 \\
(-0.54)\end{array}$ & $\begin{array}{l}-0.186 \\
(-0.21)\end{array}$ & $\begin{array}{c}5.675 \mathrm{a} \\
(3.39)\end{array}$ & $\begin{array}{c}13.045 \mathrm{a} \\
(4.48)\end{array}$ & $\begin{array}{l}22.076 \\
(0.50)\end{array}$ \\
\hline $\begin{array}{l}\text { Debt maturing } \\
\text { this year }\end{array}$ & & $\begin{array}{l}0.652 \\
(0.86)\end{array}$ & $\begin{array}{l}-0.608 \\
(-0.28)\end{array}$ & $\begin{array}{c}-11.768 \mathrm{~b} \\
(-2.54)\end{array}$ & $\begin{array}{c}-33.878 \mathrm{a} \\
(-4.99)\end{array}$ & $\begin{array}{c}-108.117 \\
(-0.70)\end{array}$ \\
\hline issued & & pre 1997 & pre 1996 & pre 1995 & pre 1994 & pre 1993 \\
\hline Country and Year FE & Yes & Yes & Yes & Yes & Yes & Yes \\
\hline Observations & 1,731 & 1,731 & 1,731 & 1,731 & 1,731 & 1,731 \\
\hline Magnitude of effect & & & & Maturing de & t issued: & \\
\hline & & pre 1997 & pre 1996 & pre 1995 & pre 1994 & pre 1993 \\
\hline one $\sigma$ change & & - & - & $-15.36 \%$ & $-25.36 \%$ & - \\
\hline
\end{tabular}

